\title{
Şâfiî̀nin Kaynak İçi Nesih Teorisi ve Şâfiî Fıkıh Geleneğinde Yorumlanış Biçimleri
}

\author{
Nail Okuyucu*
}

İslam hukuk tarihinde doktriner mezheplerin teşekkül sürecinin başladığı bir dönemde hayat süren Şafiî̀ (ö. 204/820), önde gelen fikhî çevrelerin başında bulunan Ebû Hanîfe ve Mâlik b. Enes'ten farklılaşan bir kaynak telakkisine sahiptir. Şâfiî,, rivayetler etrafındaki uğraşıların yoğunlaşmasına paralel olarak haber-i vâhidin delil değerinin arttığı bu dönemde, diğer çevrelerin bölgesel hukuk geçmişi ve genel hukuk ilkeleri çerçevesindeki bazı kabullerine karşı çıkmış ve bu kabullerden ötürü kimi zaman rivayetleri terketmelerini yanlış bulmuştur. Onun nesihle ilgili görüşleri ve yaklaşımları, bu rivayetlerin delil değerini ispat için harcadığı yoğun mesainin önemli bir başlı̆̆ını teşkil eder. Şâfiî̀nin geliştirdiği nesih anlayışının en bariz tarafı, Kur'an ve Sünnet arasında yürütülen çapraz nesih ilişkisine karşı çıkması ve hükümlerde nesih kabilinden yaşanan değişimleri kaynakların kendi içinde yürüyen bir süreç olarak ele almasıdır. Şâfiî̀nin Sünnet'in hücciyeti ile ilgili tartışmalar bağlamında önem arzeden yaklaşımı, belli bir müddet sonra mezhebini benimseyen fakihlerin sorgulamasıyla karşılaşmış ve giderek terkedilmiştir. Bu makalede, ilk olarak Şâfiî̉nin nesih teorisi, kaynak telakkisini dayandırdığ 1 esaslar bağlamında ele alınacak, ardından Şâfîi âlimlerin değerlendirmeleri ışığında mezhep içerisinde nasıl yorumlandığı üzerinde durulacaktır. Makale, Şâfiî ve Şâfiîlik üzerinden bir müçtehidin ve mezhebin usulî tavrının ve kimi usul meselelerine yaklaşımlarının bağlam içinde kazandıkları anlamı ve bağlamın değişmesiyle görüşlerin de değişebildiğini; mütekellimîn usul yazımında fürûdaki mensubiyetlerin bir noktadan sonra belirginliğini yitirdiğini ve usulî ayrışmaların mezhep mensubiyetiyle birebir örtüşmediğini göstermeyi hedeflemektedir.

Anahtar kelimeler: Şâfiî, nesih, Kur’an, Sünnet, fikıh usulü, mütekellimîn.

* Dr.Öğr. Üyesi, Marmara Üniversitesi İlahiyat Fakültesi, ORCID oooo-ooo2-8210-5361 nail.okuyucu@marmara.edu.tr Eleştirileri ve yön verici teklifleri ile makalenin olgunlaşmasına katkıda bulunan derginin adlarını bilmediğim kıymetli hakemlerine teşekkürlerimi sunarım. 


\section{I. Şâfiî Öncesinde Kaynaklar Arası Neshe Genel Bir Bakış ${ }^{1}$}

Hükümlerin teşrî sürecine dair sahâbîlerden nakledilen açıklamalar, müslümanların ilk kuşaktan itibaren nesih olgusunun farkında olduklarını göstermektedir. Bu açıklamalar, naslardaki kimi düzenlemelerin Hz. Peygamber'den tevarüs edilen sünnet ve sonraki nesillerin çalışmalarıyla $f_{\imath} k \imath h$ haline gelmiş uygulamalarda karşlık bulmaması üzerine hissedilen ihtiyaç doğrultusunda varlık bulmuş olmalıdır. İlgili hükümlerin teşrînin herhangi bir aşamasında terkedilmiş olduğunu bilen sahâbîler, tarihî süreci dikkate alarak izahata girişmiş; Kur'an’ın ve Sünnet'in gerek kendi içlerinde gerekse birbirleri arasında söz konusu olan zâhirî teâruzları giderme ve tutarlı bir bütünlük sunma gayesiyle nesih minvalinde açıklamalara başvurmuşlardır. ${ }^{2}$ İlk nesillerin kimi zaman birbiriyle de çelişen cümlelerini bütünlüklü bir değerlendirmeye tâbi tutan müteakip nesillerden müçtehitler, nesih sürecinin yaşandığı her bir örnekliği kendi içinde izah etmeye çalışmış ve bu çabaların nihayetinde birer içtihadı yansıtıyor olması, elde edilen sonuçların farklılaşmasına yol açmıştır. Zamanla müstakil mezheplere dönüşecek olan fıkıh çevrelerinin başında olan müçtehit imamların farklı nesih tespitleri, mezhepler arasındaki ihtilafların sebeplerinden biri olmuştur. Diğer taraftan, neshe dair farkındalık, uygulama ile kaynaklar arasında baş gösteren uyumsuzluğun giderilmesi için muhtelif izah biçimlerinin şekillenmesine

1 Makalenin başlı̆̆ında yer alan "kaynak" kelimesiyle, fikhın delillerinden Kur'an ve Sünnet kastedilmektedir. Metodoloji veya ilke olarak görülebilecek diğer delillerden mahiyetleri itibariyle farklılaşan bu iki delil, fikhî hükümlerin mevcut ve sabit dayanakları olmaları itibariyle kaynak olarak anılmayı hak ederler. Sünnet kelimesi bu anlamda bir kaynak olarak kullanıldığında büyük harfle, Hz. Peygamber'in (sav.) belirli bir uygulamasına işaret edildiğinde ise küçük harfle yazılmıştır. "Kaynak-içi nesih" tabiriyle delillerin kendi içinde yürüyen nesih süreci, "kaynaklar arası nesih" ve "çapraz nesih" tabirleri ile Kur’an ve Sünnet arasında yürüyen nesih süreci kastedilmektedir. Şâfiînnin nesih anlayışı, daha önceki bazı çalışmalarda ele alınmış olmakla birlikte, bu makale konuyu ele alış biçimi itibariyle bu çalışmalardan farklılaşmaktadır. Şâfiînnin fıkıh anlayışının şekillendiği tarihî bağlamın nesih anlayışının şekillenmesine etkisi, mezhebine mensup fakihlerin zaman içerisinde onun yaklaşımını yorumlayış biçimleri ve bir mezhep imamının en önemli görüşlerinden birinin aşama aşama terkediliş süreci, mezhep içinden ve mezhep dışından kaynaklanan faktörlerin fıkıh usulü yazım geleneklerinin şekillenişine etkisi ve bu bağlamda nesih konusunun işlenişinde yaşanan değişiklikler, bu makalede cevabı aranan ve yazıya yön veren sorular/meseleler arasındadır.

2 Nüzul sürecine tanıklık eden sahabe, hükümlerin teșrî sürecine dair tanıklıklarını sonraki kuşaklara aktarırken bu izah biçimine sıklıkla başvurmuş ve nesihle ilgili cümleler genel dinî bilginin ve rivayet malzemesinin önemli bir parçasını teşkil etmiştir. Önde gelen kimi sahâbîlerle erken dönem âlimlerinden nakledilen cümleler, neshe dair farkındalığı açıkça ortaya koymaktadır (Hz. Ali ve İbn Abbas başta olmak üzere önde gelen sahâbîlerden nakledilen bazı nesih açıklamaları için bk. Ebû Ubeyd, en-Nâsih ve'l-mensûh, s. 4-17). 
yol açmış, sahâbîlerin verdiği bilgilerle elde mevcut mushaf ve rivayet malzemesi bir arada değerlendirilerek neshin aşamaları ve türleri belirgin hale getirilmiştir. ${ }^{3}$ III. (IX.) asrın ikinci yarısından itibaren kaleme alınan eserlerde bütünlüklü bir nesih anlatısının ortaya konabilmesi, birkaç neslin ortak çalışmasıyla ilgili izahların tekâmül etmesi sayesinde mümkün olmuştur. ${ }^{4}$

Neshin anlam dairesinin geniş olduğu ilk iki nesilde, teşrî sürecindeki her türlü değişiklik ve naslar arasında görülen zâhirî bütün farklılıklar bu kelime ile ifade edilmekteydi. Mesela mutlakın takyidi, âmmın tahsisi, müphem ve mücmelin beyanı ve istisna gibi durumlar da nesih diye anılmaktaydı. Tahsis ve takyit gibi düzenlemelerde nihaî düzenleme amele esas alınacağı ve önceki hitap teklifin dayanağı olmaktan çıkacağı için bunlar da nesih kapsamında görülmekteydi. Şâtıbî, mütekaddimîn âlimlerinin "lafızların zâhirlerinden hükümlerin çıkarılması sırasında Şâriin maksadı olmayan mânaları vehmettiren unsurların açılanması" olarak değerlendirilebilecek her şeyi nesih diye ifade ettiklerini söyler. ${ }^{5}$ Benzer bir tespitte bulunan Şah Veliyyullah ed-Dihlevî (ö. 1176/1762), sahabe ve tâbiînin neshi sözlük anlamıyla yani "bir şeyin izale edilmesi" mânasına gelecek şekilde kullandıklarını belirtir. ${ }^{6}$ Ilk dönemdeki tespit içerikli nesih açıklamalarına, tâbiîn devrinden

3 Nesih türleri ve aşamalarının gelişim sürecini mushaf-ahkâm ilişkisi üzerinden izah etmeyi hedefleyen bir yaklaşım için bk. Burton, The Sources of Islamic Law, s. 38, $43 \mathrm{vd}$.

$4 \mathrm{Bu}$ dönemde nâsih-mensuha dair kaleme alınan eserlerden Ebû Ubeyd'in enNâsih ve'l-mensûh'u ile Ebû Ca'fer en-Nehhâs'in (ö. 338/950) en-Nâsih ve'l-mensûh fî Kitâbillâhi azze ve celle ve'htilâfül-ulemâ' fî zâlik'i, nesih bilgisinin oluşumuna ciddi katk1 sunmuştur. Yine Hâris el-Muhâsibînin (ö. 243/857) el-Akl ve fehmü̉l-Kur'ân’’ ile İbn Kuteybe’nin (ö. 276/889) Te’vîlü muhtelifi'l-hadîs'inin ilgili bölümleri, nesih bilgilerini derinleştiren ve kısmen farklılaşan yaklaşımları barındıran eserlerdir. V. (XI.) asırdan itibaren kaleme alınan nâsih-mensuh eserlerinde yer verilen bilgi ve değerlendirmeler önemli ölçüde bu kitaplara dayanır (literatür hakkında bk. Zeyd, en-Nesh, I, 290-395; Birışık, "Nesih", s. 584-86).

5 Şâtıbî, el-Muvâfâkāt, III, 364. Şâtıbînin verdiği örnekler, hem bu genel kullanımı ortaya koymakta hem de neshin henüz ahkâm alanıyla sinırlandırılmadığı bir süreçte muhtelif konu ve alanlara dair naslar arasında nesih ilişkilerinin nasıl kurulduğunu göstermektedir. Mesela İbn Abbas'tan naklettiği nesih açıllamaları ihbârî âyetlerle ilgili olabilmekte, âyetlerdeki istisnalar nesih olarak adlandırılmakta, araları bir şekilde tevil edilebilecek farklı âyetler de nâsih-mensuh sayılmaktadır. Benzer rivayetler İbn Mes'ûd, Ebü'd-Derdâ gibi sahâbîlerin yanı sıra Atâ b. Ebû Rebâh, Vehb b. Münebbih, İbn Şihâb ez-Zührî, Katâde gibi tâbiîn âlimlerinden de nakledilmektedir. Bu isimlerin tefsir ilminde açıklamalarına müracaat edilen erken dönem otoriteleri olması kayda değer bir husustur (bk. Şâtıbî, el-Muvâfâkāt, III, 344-64).

6 Şah Veliyyullah, ilk başta bir âyette zikredilen bir vasfın başka bir âyetle değiştirilmesine nesih dendiğini ve tahsis, istisna gibi durumların da bu kelime ile ifade edildiğini belirterek kelimenin böylesine geniş bir anlam dairesine sahip olmasını bu hususa bağlar (el-Fevzü̉l-kebîr, s. 83-84). İmam Eş'arînin neshin anlamları olarak sıraladığ 
itibaren tanım olarak görebileceğimiz cümleler de eşlik etmeye başlamıştır. ${ }^{7}$ Nesihle ilgili çağdaş kimi araştırmalarda, mütekaddimîn devrindeki bu anlam genişliğinin Şâfiî ile daralmaya başladığı ve onun neshi tahsis, takyit gibi diğer açıklama türlerinden ayıran kişi olduğu dile getirilir. ${ }^{8} \mathrm{Bu}$ tespit bütünüyle doğru kabul edilecek olursa Ebû Hanîfe önderliğindeki Kûfe fikıh çevresinin nesih teorisine sundukları katkılar göz ardı edilmiş olur.

Nesihle ilgili ilk eserlerden birinin müellifi kabul edilen Katâde b. Diâme’nin (ö. 117/735) genç bir çağdaşı konumundaki Ebû Hanîfe (ö. 150/ 767), konuya dair açılamalarıyla teorinin gelişimine katkı sağlayan ilk âlim olarak görülmeyi hak eder. Ebû Hanîfe, geçmişten intikal eden kabulleri, "Muhakkak ki Allah’n kitabında nâsih ve mensuh vardır. Hz. Peygamber'in hadislerinde de nâsih ve mensuh vardır" diyerek kurallaştırmış, "Şüphesiz biz biliyoruz ki, Hz. Peygamber bir âyeti iki farklı şekilde tefsir etmemiştir. Kur'an’ın nâsih olan âyetini herkes için nâsih, mensuh olan âyetini de herkes için mensuh olarak tefsir etmiştir” diyerek Resûlullah’n sözlerini öne çıkarmak suretiyle kaynaklar arası nesih ilişkisini tesis etmiş; böylelikle nâsih ve mensuh âyetlerin Hz. Peygamber tarafından bildirilmiş olduğu ilkesini vazetmiștir. ${ }^{9}$ Ebû Hanîfe'nin nesih teorisine sağladığı en önemli katkı, neshin sahasını tayin etmeye yönelik açılamalarıdır. Erken dönemdeki geniş kullanımı daraltma ihtiyacı hisseden Ebû Hanîfe, neshi naslar arasında vâki farklılıkların bütünü için kullanılan bir üst kavram olmaktan çıkararak daha sonraları yerleşecek olan istılahî anlamına yaklaştırmıştır. ${ }^{10}$ Ebû

hususlar, kavramın erken dönemde hangi anlamlarda kullanıldığını göstermesi bakımından önem arzeder (bk. Makālât, II, 276-77).

7 Mesela Dahhâk (ö. 105/723) neshi "unutturma” diye açıklarken, Atâ b. Ebû Rebâh (ö. 114/732) “Kur'an'dan terkedilenler", Süddî ise (ö. 127/745) "hükmü kaldırılan” diye niteler (bk. İbn Kesîr, Tefsîr, I, 215).

8 Zeyd, Şâfiînnin neshi "farzın terki" olarak tanımlamak suretiyle onu takyit, tahsis ve istisna kavramlarından ayıran ilk kişi olduğunu söyler (bk. en-Nesh, I, 91 vd.).

9 Ebû Hanîfe'nin nesihle ilgili kabul ettiği sahabe kaynaklı rivayetler, esasında Hz. Peygamber'in açıklamalarına dayanan bilgiler olarak görülmüş olmalıdır. Hanefî usulünde kabul gören Kur'an’ın Sünnet tarafından neshedebileceği, Ebû Hanîfe'den itibaren benimsenen bir görüştür (bu konuda Ebû Hanîfe'ye nispet edilen görüşlerin sıhhatine dair bir değerlendirme için bk. Tok, "Ebû Hanîfe'nin Nesih Anlayışı”, s. 24-27).

10 Ebû Hanîfe'ye nispet edilen "Kur'an'daki ilahî sıfatlara ve haberlere gelince, bunların hiçbirinde mensuh yoktur. Nâsih ve mensuh ancak emir ve nehiyde cereyan eder", "Nesih dinde değil, şeriatta olur" cümleleri, neshin sahasını tayin etmeye dönük önemli ifadelerdir. İçtihatta bulunurken nâsih ile mensuhu birbirinden ayırt etmekte oldukça titiz davrandığı nakledilen Ebû Hanîfe, özellikle hadislerin buna riayet edilmeden aktarılması halinde ne gibi hatalara düşüleceğine dikkat çeken cümleler serdetmiştir (uyarı niteliğindeki bir cümlesi için bk. bk. el-Âlim ve'l-müteallim, s. 15-16; Mekkî, Menâkıb, s. 87). 
Hanîfe, kaynaklar arası nesih ilişkisi hususunda sahabe ve tâbiîn devrindeki genel kabulün dışına çıkmamış, hem Kur'an’nn Sünnet'i hem de Sünnet'in Kur'an’ı neshedebileceğini kabul etmiştir. ${ }^{11}$ Aynı dönemde yaşayan Mukātil b. Süleyman’ın (ö. 150/767) nesihle ilgili açıklamaları, Ebû Hanîfe’nin bahsi geçen sınırlandırıcı yaklaşımına karşın genel kanaatin hâlâ eski tasavvurlara daha yakın olduğunu göstermektedir. ${ }^{12}$ Ebû Hanîfe'nin neshin kavramsal içeriğini belirlemek için başlattığı bu girişim henüz bütün ilmî muhitlerde karşılık bulmadığı için eski kullanıma devam edilmiştir. Mukātil'in tefsiri, Kur'an-Sünnet arasındaki nesih ilişkisine dair yaygın kabulü eserine yansıtmış olması bakımından da önemli bir kaynaktır.

\section{II. Şâfiî̀nin Kaynak Telakkisi ve Bu Telakki İçinde Neshin Yeri}

Şâfiî̀nin kaynak telakkisi, Hanefîler'in bilinen sünnet (sünnet-i ma'rûfe) ve yaygınlık kazanmış uygulamalara (amel-i mütevâres) dayanan ve kıyas düşüncesiyle sistemleștirilen fikıh anlayışlarıyla Mâlikîler'in amel-i ehl-i Medîne’yi esas alan telakkilerine yönelttiği tenkitler etrafında şekillenmiştir. Onun er-Risâle'de ısrarla savunduğu, içtihadın kıyasla ve hadisin sünnetle özdeş oluşu, bu telakkinin dayandığ 1 iki umdedir. ${ }^{13}$ Şâfiî̀den önce şekillenen fıkıh çevrelerinde, hadis rivayetleri ile sünnetler arasında fark gözetilmekte ve münferit rivayetlerle müslüman kamuya mal olmuş uygulamalar arasında hiyerarşik bir ayırıma gidilmekte idi. Bu uygulamaların Sünnet'e dayandığ1na ve onu temsil ettiğine inanılıyor ve onlarla çelişen rivayetler kimi zaman doğrudan reddedilirken kimi zaman ilave birtakım kıstaslara tâbi tutularak Sünnet'e dahil ediliyordu. İşte Şâfîi, hâkim kaynak telakkilerini dönüştürme

11 Kur'an'da yer alan hükümlerle birebir örtüşmeyen hadislerle karşılaştığında Ebû Hanîfe'nin behemehal nesih açıklamasına başvurmadığı, arz yöntemini devreye soktuğu veya Kur’an’ın ilgili hadisi neshettiğini söylediği de görülmektedir (bk. Tok, "Ebû Hanîfe'nin Nesih Anlayışı”, s. 26-27).

12 Neshi tanımlayan ve unsurlarına dair birtakım açılamalar getiren Mukātil, ilk nesillerdeki gibi tahsisi, takyidi ve beyanı da nesih olarak adlandırmaya devam etmiștir. Bununla birlikte, nesihle ilgili kimi açılamaları, Mukātil'in genel bir nesih anlayışına ulaştı̆̆ına dair kuvvetli karineler sunar (bu açıklamalar ve değerlendirmesi için bk. Altay, "Mukâtil b. Süleyman Örneğinde Erken Dönem Nesih Algısı", s. 45-66).

13 er-Risâle, s. 453 (p. 1238-39), 477 (p. 1323-24). Şâfiî, bu cümlelerle her iki çevreye yönelttiği tenkitleri iki esaslı başlıkta toplamıș ve bunlar üzerinden yeni bir kaynak telakkisine ulaşmayı hedeflemişti. İlk cümle, hususan Hanefîler'in istihsan anlayışını hedef alan ve içtihat faaliyetini kıyasla sınırlandıran bir özdeşlik kurma gayretine işaret ederken ikinci cümle her iki çevrenin Sünnet anlayışını da tenkit eden ancak daha ziyade Medine merkezli Mâlikî fikıh anlayışını hedef alarak rivayetlerin konumunu pekiştiren bir vurguya sahiptir. Şâfiînnin yeni fıkıh anlayışının en belirgin yönlerinden birine işaret eden bu hadis vurgusu, aynı zamanda fikıh tarihinde önemli bir dönüm noktasını temsil eder. 
gayesiyle hadisleri sünnetle özdeş kılarak rivayetlere o vakitlerde sahip olduğu hüccet değerinden daha fazlasını tanıma yönünde bir hamlede bulundu. Tabii ki o, yerleşik hale gelen ve genel kabul gören bütün uygulamalarla mücadele etme yoluna girmedi; bunun yerine söz konusu uygulamaların $\mathrm{Hz}$. Peygamber'in örnekliğindeki köklerini belirgin kılmaya çalıştı. Bunun için rivayetlere itimat edilmesi gerektiğini düşünerek bunları âhâd dahi olsalar Sünnet'i yansıtan sahih bilgi kaynakları olarak daha yukarı bir mevkiye taşımak istedi. Şâfiînnin bu çabası, ehl-i hadis çevrelerinin hassasiyetlerine de uygun düşecek şekilde Sünnet'in konumunu pekiştirmek ve Sünnet bilgisini yansıttığına inandığı rivayetleri tahkim etmeyi hedefler. Bunun için Kur'anSünnet ilişkilerini yeniden kurgulamak gerekiyordu. İşte bu kurgunun en önemli başlıklarından birini nesih teşkil etmiştir.

Şâfiî, kaynak telakkisi ışı̆̆ında bütüncül ve tutarlı bir nesih teorisi geliştirirken Sünnet'in hücciyeti ve sübutu etrafında II. (VIII.) asır boyunca yaşanan tartışmalar çerçevesinde şu üç görüşe cevap vermek durumunda kaldı: a) Kư’an bağlayıcı tek kaynaktır; onda her şey açıklandığ kaynaklara ihtiyaç yoktur, dolayısıyla Sünnet'i aktaran haberlere itimat edilemez. b) Kur'an hâkim tek kaynaktır; herhangi bir âyetle teâruz eden hadis rivayetlerinin kaynaklık değeri yoktur, dolayısıyla haberlerin kabul edilebilmesi için Kur'an'daki hükümlerle uyumlu olmaları gerekir. c) Kur’an’n zâhir ve umum nitelikli ifadeleri karşısında haber-i vâhitlerin herhangi bir değeri bulunmamaktadır; bu türden âyetlerle teâruz eden rivayetlere itibar edilmez. Şâfiî, ilk iki yaklaşımı ehl-i kelam diye andığı çevrelere nispet eder. Üçüncü yaklaşımsa Hanefîler'e aittir. ${ }^{14}$ Hanefîler, Kur’an-Sünnet ilişkisini dil ve nasların yorumu için geliştirdikleri kavramlar çerçevesinde tesis ettikleri için neshi de bu bağlamda ele alırken Şâfî̉nnin nesih teorisine yön veren ana fikir, Kur’an-Sünnet birlikteliği olmuştur. Şâfiînnin dilinde bu birliktelik, neredeyse bütünüyle özdeşliği savunacak kadar ileri taşınmıştır. Şâfiî,, Sünnet'i Kur’an ile eşdeğer bir hücciyet seviyesine taşıyarak kelamî çevrelerce dillendirilen ve onun nazarında Sünnet'in konumunu sarsan görüşlere cevap verirken aynı zamanda $f_{\imath} k$ ıh haline gelen hükümler dizgisinin zeminini de tahkim etmiş oluyordu. ${ }^{15}$ Onun biraz sonra tafsilatıyla aktarılacak olan nesih anlayışında bir yandan Kur'an ile Sünnet'i özdeş kılar gibi görünürken diğer yandan bu iki kaynağı müstakil deliller olarak görmek isteyişi, mezkûr endişelerin yön verdiği bir arayışın neticesi olmalıdır.

14 Şâfiî, Cimâu’l-ilm adını verdiği risalesini bu çevrelerin görüşlerini tartışmak ve geçersiz kılmak için kaleme almıştır (bu risaleden hareketle kaleme alınmış bir makale için bk. Aktepe, “İmam Şâfîinnin Ehl-i Kelâm ve Mâlikîlere Karşı Hadis Savunusu”, s. 111-33).

15 Benzer bir değerlendirme için bk. Burton, The Sources of Islamic Law, s. 36-37. 
Şafiî, delillerin hükümleri bildirme keyfiyetlerini açıklamak ve kaynaklar arası ilişkileri tesis etmek üzere "beyan" kavramının merkezinde olduğu bir teori geliştirmiş ve er-Risâle'nin başında yaptı̆̆ beşli tasnifte teorisinin ana hatlarını aktarmıştır. ${ }^{16}$ er-Risâle’nin muhtevasının bu taksim doğrultusunda şekillendiği görülmektedir. Metnin bütününe yansıyan ifadeler, yine bu taksimde sunulan düşünceyle anlam kazanır. Şâfiî beyan taksiminde ilk dört maddeyi, Kur'an ile Sünnet'in hükümleri beyan ediş keyfiyetlerine ayırmış olup burada kaynakların hükümleri hem müstakillen hem de bir arada vazetme yollarını göstermekte, kaynakların birbirini nasıl tamamladığını ele almaktadır. er-Risâle'nin ilerleyen bölümlerinde beyan türleriyle ilgili muhtelif durumları ele alan başlıklar, nasların tutarlı ve bütünlük arzedecek biçimde nasıl anlaşılacağı sorusuna odaklanmış ve aslında bir yönüyle zâhirdeki teâruzların giderilebileceği yolları göstermeyi hedeflemiştir. Bu başlıklarda karşımıza çıkan âm-hâs ve mücmel-mübeyyen kavram çiftleri, beyanın öğeleri olarak sunulur.

Şafiî, ilk olarak âm-hâs ayırımını ele alarak naslardan umum-husus nitelikli ifade ve hükümlerin nasıl anlaşılması gerektiğini açıklamış, daha sonra mücmel-mübeyyen arasındaki farklara değinmiş ve nihayet bu yorum tekniklerinin işletilemeyeceği yerde nesih izahına başvurmuştur. Şâfiî, nâsihmensuhu müstakil bir beyan öğesi olarak ileri sürmemiş, neshi beyan sürecinin gerçekleşmesi akabinde ortaya çıkan nihaî durumu açıklama aşamasında devreye sokmuştur. Âm-hâs ve mücmel-mübeyyen çiftleriyle nâsih-mensuh çiftinin teorideki yerini farklılaştıran husus, bu çiftler arasındaki farkın yorum faaliyetiyle giderilmesinin mümkün olup olmamasıdır. Naslar arasındaki zâhirî teâruzları herhangi birinin hükmünü iptal etmeden gidermeyi mümkün kılan yorum teknikleri beyan kapsamında görülürken bu yorum tekniklerinin tüketilmesi durumunda son çare olarak nesih açıklamasına başvurulmaktadır. Nesih, tarihsel bir sıralamaya tâbi tutulan naslar arasında

16 Şâfiî, beyan kelimesini tercih ederken Kur’an’n her şeyi açıkladığını bildiren ve Hz. Peygamber'e beyan vazifesini yükleyen âyetlerden (en-Nahl 16, 44, 89) etkilenmiş olmalıdır. Şâfiî beyanı, "Asılları itibariyle bir, fer'leri itibariyle farklılıklar taşıyan anlamları topluca ifade eden kavram (isim)" olarak nitelendirir (er-Risâle, s. 21 [p. 53]). Bu teoride, ilahî iradeyi mükelleflere taşıyan kaynaklar beyanın muhtelif türleri olarak görülmüş ve aralarındaki ilişki biçimlerine göre şekillenen bir taksim geliştirilmiştir. Bir anlamda edille-i şer'iyye sıralaması olarak görülebilecek beyan taksimi şu beş başlıktan oluşur: 1. Kur’an nassı ile yapılan beyan. 2. Kur'an’ın kısmen mücmel biraktığg ve Sünnet tarafından bu mücmel kısma açıklık getirilen durumlardaki beyan. 3. Kur'an’ın mücmel hükümlerinin Hz. Peygamber’in Sünneti ile açılıl̆g kavuşturulması şeklindeki beyan. 4. Kur'an nassı ile belirlenmeyip Hz. Peygamber'in Sünneti ile teşrî kılınan hükümlere ait beyan. 5. Allah’ın içtihat yoluyla araştırılmasını emrettiği hususlara ait beyan (bk. p. 55-105). 
kurulan ve birinin diğerini kısmen veya bütünüyle geçersiz kıldığ ilişkiyi ifade ederken, diğer teknikler aralarında gerçekte teâruz bulunmayan ancak zâhirde farklılaşan nasların nasıl yorumlanabileceğini göstermek amacıyla geliştirilmiştir. ${ }^{17}$ Böylelikle, bir konuyla ilgili naslardan evvelemirde hiçbirini devre dişı bırakmadan geliştirilecek yorumlara beyan dahilinde teorik bir çerçeve kazandırılmıştır. Nesih bu yönüyle beyan öğelerinden farklılaştığ 1 için Kur'an bilgisinin kapsamında nelerin bulunduğu sıralanırken nesih yine farklı bir madde olarak zikredilir. ${ }^{18}$

Şâfiî, nesih ile muhtelif beyan türlerinin birbirine karıştırılmaması gereğine işaret ederek ilk bakışta çelişir gibi gözüken naslar arasında nesih üzerinden bir karşıtlık kurmanın yanlış olacağını belirtir. ${ }^{19}$ Arapçảnın taşıdığı dil özellikleri sebebiyle hükümlerin ifade edilişi sırasında bazı farklılıklar yaşanabileceğine dikkat çekerek bunların nesihle karıştırılmaması yönünde bir uyarıda bulunur. Mesela zâhiren âm olan bir âyet gerçekte hâs nitelikli olabilir. Kimi zaman bizzat Kur’an’n kimi zaman da sünnetin delalet ettiği bu gibi farklılıklar hemen nesih sayılmamalıdır. Şâfiî, beyan ile neshin birbirine karıştırılmaması adına kullandığı kelimeleri de özenle seçmiş, Sünnet' in Kur'an'ı tahsisi olarak görülebilecek yerlerde dahi ısrarla beyan, tefsir ve delalet gibi kelimeleri kullanmıştır. ${ }^{20}$ Bu kullanım ve hassasiyetler, Şâfiî̉nin kaynak ve yorum teorisinde neshi gerçekleşme aşamaları itibariyle beyanın bir öğesi saymadığına, bilakis süreç sonunda başvurulan bir açıklama modeli olarak gördüğüne işaret etmektedir. Lowry’nin de belirttiği üzere, beyan teorisinin uzantısı mahiyetinde olan nesih tasavvurunun bu teori ile çelişmemesi gerekiyordu. Bunun için Şafîî, Kur'an ile Sünnet arasında kurduğu ilişki gereği, bu iki kaynağın mahiyetlerinin farklı olduğunu ve birbirlerini neshetmediklerini ileri sürecektir. Zira kaynaklar arası nesih kabul edildiği

17 Lowry, Early Islamic Legal Theory, s. 87. Sahip Beroje, “İmam Şâfiînnin Nesh Anlayışı ve İlk Şâfiî Usulcülerin Buna Yönelik Eleştirileri” başlıklı makalesinde, Şâfiînnin neshi bir beyan türü olarak gördüğünü söyler. Bu cümle, Şâfiînnin beyan tasavvuruyla ve beyanın öğeleri olarak sıraladığı kavram çiftleriyle uyumlu görünmemektedir (bk. s. 55-56; nesih ile tahsis arasındaki farklar için bk. Koca, İslâm Hukuk Metodolojisinde Tahsis, s. 119-24).

18 Şâfiî, nâsih-mensuh bilgisi ile Hz. Peygamber'in beyan nitelikli açılamalarını, nesih ile Hz. Peygamber'in beyan ettiği Kur’an hükümlerinin farklı bilgi alanlarına karşılık geldiği kabulünden hareketle ayrı maddeler olarak sunmuştur (bk. er-Risâle, s. 40-41 [p. 127-30]).

19 Şâfiî, Kur'an’ın ve Sünnet'in hüküm koyma tarzlarından bahsettiği bir yerde şöyle bir sıralama yapar: 1. Allah’n nas olarak indirdiği farîzalar (p. 421). 2. Beraberinde Sünnet'in de olduğu mansûs farîzalar (p. 448). 3. Sünnet'in, kendisiyle hâssın kastedildiğine delalet ettiği mansûs farzlar (p. 466). 4. Mücmel farîzalar (cümelül-ferâiz, p. 486).

20 Bk. er-Risâle, s. 91 (p. 298), 106 (p. 315), 110 (p. 330), 221-22 (p. 608-609). 
takdirde beyan teorisinin bir anlamı kalmayacaktı. Şâfiî teoriyi geliştirirken kaynakların birbirini tamamladığı fikrinden hareket ettiği için âyet ve hadislerin birbirini neshettikleri kabul edildiği takdirde beyan teorisi geçerliliğini yitirmiş olacaktı. ${ }^{21}$

\section{III. Şâfiînnin Kaynak İçi Nesih Teorisi}

Kur'an-Sünnet münasebetini, kaynakları mahiyet ve hücciyet değerleri bakımından birbirine yaklaştırarak tesis eden ve Sünnet'e tanıdığı mevki ile özellikle ehl-i hadis çevrelerinde etkili olan Şâfiî, nesih söz konusu olduğunda bu yaklaşımdan beklenecek en olası sonucu terkederek kaynakları birbirinden ayrı değerlendirmek gerektiğini savunur. Neshi Kur'an’n ve Sünnet' in kendi içlerinde yürüyen bir süreç olarak tasarlayan Şafiî̀, ne Kur'anı̉ı Sünnet'i ne de Sünnet'in Kur'an’ı neshetmiş olabileceğini kabul eder. Kur'an-Sünnet ilişkisini kurgulayışı ve bir bütün olarak Sünnet'in vahye müstenit olduğu fikrini ısrarla savunan Şâfiî, aslında her ikisinin de aynı kaynaktan geldiğini kabul etmesine rağmen rivayetlerin geçerliliğine gölge düşüreceğinden korkmasına yol açan birtakım endişelerden ötürü Sünnet' in Kur’an’ı neshine karşı çıktı. ${ }^{22} \mathrm{O}$, kaynak-içi nesih teorisini, kaynakların mahiyet bakımından

21 Lowry, Early Islamic Legal Theory, s. 90-91. Lowry, Şâfiînin neshi pratikte âm-hâs ayırımı gibi işlettiğine de dikkat çeker (Early Islamic Legal Theory, s. 103). Şâfiînnin ilgili cümleleri, neshin unsurları ve işlevlerine dair kanaatlerini açığa çıkarmakla birlikte, onun bir nesih tanımı yaptığını söylemek zordur. $\mathrm{O}$, ilgili cümlelerinde neshedilen hüküm ile sabit kılınan hükmü birbirinin mukabili olarak kullanmakta, neshi "farziyetin terki", mensuhu "farziyeti kalkmış" ve de nâsihi -Kur’an üzerinden"Allah’n önceden indirdiği bir emre muhalif olarak daha sonradan indirdiği emir" diye tanımlamaktadır. Menderes Gürkan, er-Risâle ve İhtilâfül-hadîs'teki bu ifadelerden hareketle Şâfiînnin nesih düşüncesinin temel unsurlarını tespit etmiştir (“İmam Şafii Öncesi Nesih Kavramı”, s. 844). Şâfiî̀den sonra neshin mahiyetine de ışık tutacak şekilde tanımlanmasına dönük ihtiyaç, iki farklı nesih tasavvurunu beraberinde getirmiştir. Hanefîler'in ağırlıklı olduğu bir usulcüler grubu neshi "hükmün müddetinin beyanı" olarak tanımlarken Şâfiîler'in çoğunlukla benimsediği diğer bir tanıma göre nesih, “önceki hükmün kaldırılması"dır. Debûsî ve onu takip eden bazı önemli usulcüler, nesih Allah açısından bir beyan olsa da kul açısından bakıldığında bir tebdil ve ref ${ }^{\star}$ işlemidir. Davut İltaş, Pezdevîden itibaren Hanefîler'de bu görüşün ağırlık kazandığını belirtir (bk. Klasik Nesih Teorisi, s. 31).

22 Burton, İslam hukuk düşüncesinde nesih düşüncesinin ortaya çıkışı ve gelişimi üzerine yazdığı kitapta, nesih teorileri tekâmül ederken müslümanların Kur'an, Sünnet ve mevcut ahkâm arasında söz konusu olan zâhirî uyumsuzlukları çözmekle meşgul olduklarını ve nihayetinde Sünnet'in de vahiy kapsamında görülmesiyle problemin çözüldüğünü belirtir. Burton, Kur’an-Sünnet arasında çapraz neshin kabul edilişini, ehl-i hadisin Sünnet'in hücciyeti hususunda elde ettiği zaferin kaçınılmaz neticesi olarak görür (The Sources of Islamic Law, s. 4-8, 25). Bu değerlendirmeye o dönemde c1lız da olsa varlık bulan ve sadece Kur'an'da yer alan hükümleri dikkate alan yaklaşımı göz önünde bulundurarak hak vermek mümkün olsa da Hanefîler'in başını çektiği ehl-i 
tefriki, neshin ortaya çıkış süreci, bu süreçte Kur’an-Sünnet arasındaki münasebet ve nesih bilgisinin bize ulaşma şekli ve yolları gibi hususlarla ilgili esaslar üzerine bina etmiştir.

Şâfiî, nesih söz konusu olduğunda Kur’an ile Sünnet'i bağımsız kaynaklar olarak kabul eden bu yaklaşımıyla, hâkim fikıh çevrelerinin sahabeden gelen nakiller üzerine tesis etmiş bulundukları kabullerden farklılaşarak nesih meselesini farklı bir düzleme taşımak istemiştir. ${ }^{23}$ Kaynaklar arasındaki nesih ilişkisini bütünüyle reddeden bu görüş, bilindiği kadarıyla ilk defa Şâfiî tarafından ileri sürülmüştür. ${ }^{24}$ Şâfiî bu yaklaşımını, Kur’an-Sünnet ilişkilerini yerleştirdiği zemine dayandırır ve ilişkilerin üç hat üzerinde yürüdüğünü söyler. Bu hatlar; 1. Kur’an'da nas olarak nâzil olan hükümleri Sünnet'in tıpk1 bu nastaki gibi açıklaması (tebyin). 2. Kur'an'da mücmel olarak nâzil olan hükümlerde Allahı̀n muradının ne olduğunu Sünnet'in açıklaması (tebyin). 3. Kur'an'da bir nassın yer almadığı durumlarda Sünnet' in müstakillen hüküm koymasıdır. ${ }^{25} \mathrm{Bu}$ üç hattı detaylandıran Şâfiî, Kur'an ile Sünnet'in bir arada olduğu durumları beş başlıkta ele alır:

1. Kitapta yer alan nâsihler ve mensuhlar hakkında Sünnet'ten hareketle yürütülen istidlal,

2. Beraberinde Sünnet'in de bulunduğu mansûs farîzalar,

3. Hz. Peygamber’in beyan ettiği mücmel farîzalar,

4. Allah’n âm mânayı murat ettiği âm âyetleri ve hâs mânayı murat ettiği âm âyetleri (sünnetin açıllaması),

5. Kitap nassının olmadığı yerlerde vücut bulmuş sünnetler. ${ }^{26}$

Buna göre, Şâfiî Sünnet'in Kur'an hakkındaki beyanını üçe ayırmış olmaktadır: a) Nâsih-mensuhun beyanı, b) Mansûs-mücmelin beyanı, c) Âmhâssin beyanı.

re’y kesimleri karşısında isabetli olduğunu söylemek mümkün değildir. Zira Hanefîler de Sünnet'in hücciyetini en az diğer çevreler kadar kabul ediyor ve makalenin girişinde işaret edilen birtakım kıstaslar dahilinde rivayetleri delil olarak kabul ediyorlardı.

23 Kaynaklar arasındaki nesih ilişkisini izah etmeyi hedefleyen beş farklı yaklaşım için bk. Nehhâs, en-Nâsih ve'l-mensûh, s. 53 .

24 Sünnet'in Kitap ile neshine karşı çıan ilk kişinin Şâfiî olduğu hakkında bk. Cessâs, el-Füsûl, II, 18-19. Ebû Hanîfe'nin Sünnet'in Kur'an'a arzı bağlamındaki tavrı, Sünnet'in Kur'an’ı neshini kabul edip etmediği açısından tartışlabilir ise de onun Kur'an’ın Sünnet'i neshettiğini kabul ettiği kesindir. Yine İmam Mâlik'in Kur'an’’n Sünnet ile neshine karşı çıktığına dair nakiller bulunmakla birlikte (Gazzâlî, el-Menhûl, s. 387), mezhepte benimsenen ve imama nispet edilen hâkim görüş aksi yöndedir (bk. Karâfî, Şerhu Tenkīhil-fusûl, s. 245-46).

25 er-Risâle, s. 91-105 (p. 299-309).

26 Bk. er-Risâle, s. 105 vd. (p. 311 vd.). 
Kur'an'da zikredilmiş bir hükmü yine Kur'an neshedebilir. Sünnet böyle bir şey yapamaz, onun yetkisi şu iki hususla sınırlıdır: a) Kur'an'da açık (nas) bir hüküm geldiğinde ona tâbi olarak benzerini ortaya koymak. b) Kur'an'da mücmel bir hüküm geldiğinde mânasını tefsir etmek. ${ }^{27}$ Sünnet'in Kur’an karşısındaki konumu takrir/teyit ve beyan etmekten ibarettir. Bir sonraki aşamaya geçerek ondaki hükümleri herhangi bir şekilde değiștirme yetkisi yoktur. Dolayısıyla Şâfiînnin tasavvurunda nesih ilişkisinin kendisi beyanın dışında bir işlem olarak görüldüğü için bu tasnife dahil edilmemiştir. Şâfî̉nin bu husustaki en önemli dayanakları, Hz. Peygamber' in kendisine indirilene tâbi olmak zorunda olduğunu ve Allah’n koyduğu hükümleri kendiliğinden değiștiremeyeceğini bildiren, hükümleri kaldırma yahut sabit bırakma yetkisini Allah’a özgü kılan âyetlerdir (Yûnus 10/15; Ra'd 13/39). Yine Allahìn neshi ve tebdili kendisine nispet ettiği âyetler de (Bakara 2/106; Nahl 16/101) Şâfî̉nin dayanakları arasındadır. Şâfiî, aynı noktadan hareketle, bir sünneti ancak bir başka sünnetin neshedebileceğini dile getirir. Mevcut bir sünnetin değişmesi gerekmişse Allah, resulüne bildirir ve Resûlullah da bunun gereğince eski sünnetini değiştirir; insanlara eski sünnetinden farklı, yeni/nâsih bir sünneti olduğunu açılar.

Kaynakların kendi içlerinde yürüdüğü var sayılan nesih süreçlerinin muhataplar tarafından nasıl bilineceği ve âyetlerle hadislerin hangisinin nâsih hangisinin mensuh olduğunun nasıl ayırt edileceği gündeme geldiğinde, Şâfiî̀nin izahı yine Sünnet'in belirleyiciliğini öne çıaracaktır. Şöyle ki; Kur'an içindeki nâsihlerin birçoğu Sünnet'in delaletiyle bilinebilecek iken Sünnet içindeki nâsih-mensuhlar zamansal önceliğe-sonralığa göre belirlenecektir. Sünnet'i yansıtan rivayetler içerisinde zamana dayalı bir tespit yapmak mümkün olduğu halde âyetler arasında bunun tespiti her zaman mümkün olmadığı için Kur'an'daki nesih problemlerinin çoğu ancak Sünnet bilgisiyle aşlabilir. Kur'an’’n kendi içindeki sürecin bilgisi dahi Sünnet'e bağlı olduğuna göre, bu husus Sünnet için evleviyetle geçerli olacaktır. Bu durumda, Hz. Peygamber'in neshedici sünneti olmaksızın Kur'an’ın Sünnet'i neshinden bahsetmek anlamsız olur. Eğer bir âyet geçmiş sünnetin hükmünü ortadan kaldırmış ise yani Kur'an Sünnet'i neshetmişse bunu gösteren nâsih bir sünnet bulunmak zorundadır. Aksi takdirde mesele çözümsüz hale gelecek, hangi âyet ve hadislerin nâsih, hangilerinin mensuh olduklarını bilmek imkânsız olacaktır. ${ }^{28} \mathrm{Bu}$ da netice itibariyle vahiy sürecinin tersine çevril-

27 "Allah şunu beyan etti: Kitapta sabit bir hükmü yine kitap ile nesheder. Sünnet kitabı neshedemez. Sünnet, ya nas olarak nâzil olmuş hükümlerin mislini getirmek suretiyle kitaba tâbidir ya da Allah’̉n mücmel olarak indirdiği hükümlerin mânalarını açıklar (müfessir)" (bk. Şâfiî, er-Risâle, s. 106 [p. 314]).

28 Şâfiî, er-Risâle, s. 221 (p. 608). Şâfiî, kendi nesih teorisinin kabul edilmemesi halinde doğabilecek aksaklıklara şunları örnek gösterir: "Hırsızlıkla ilgili nisap bildiren hadis 
mesine, Kur’an-Sünnet ilişkisinin bütünüyle tersyüz edilmesine götürecek ve Hz. Peygamber'in neredeyse bütün sünnetleri boşa çıkacaktır. ${ }^{29}$ İhtilaflı hadisler arasında nâsih-mensuh tespiti yapmaya imkân veren bir zaman karinesi bulunamadığ tercih seçeneği kalmaktadır. ${ }^{30}$

Şâfiî, kaynaklar arasında mahiyetleri bakımından bir ayırıma giderek nasıl Kur'an’a denk başka bir söz yoksa Sünnet'e denk başka bir sözün de olmadığını, bu yüzden Sünnet’ i yalnızca yine Sünnet' in neshedebileceğini söyler. ${ }^{31}$ Şâfiînnin Sünnet'in hiçbir insan sözünce neshedilemeyeceğine dair israrlı vurgusu, dönemin yaygın tartışma konuları hatırlandığında daha da anlamlı hale gelmektedir. O, muhtemelen diğer fikıh çevrelerinde haber-i vâhid üzerinden yaşanan tartışmaları bu bağlama yerleştirerek farklı gerekçelerden ötürü rivayetlerin reddedilişini "nesih" olarak takdim etmekte ve böylelikle muhalifleri asla cüret edemeyeceklerini düşündüğü bir sonuçla ilzam etmek istemektedir. Hz. Peygamber'den sonra hiçbir kimse nâsihlik iddiası ile ortaya çıkmadığı halde Şâfî̀ belli bir tavrı üstü kapalı olarak bununla ilişkilendirerek muhtemelen Hanefî ve Mâlikîler’i yaptıkları yorumlarla farkında olmadan da olsa nâsihliğe soyunmakla itham etmektedir.

Kaynaklar arasındaki nesih ilişkisini mahiyet bakımından farklılık ve Kur'an’ın Sünnet'ten mutlak mânada üstünlügü ile temellendiren Şâfiî, vuku bulmuş mevcut nesih işlemlerinin bize nasıl intikal edeceğini yine benzer endişelerden hareketle bahse konu eder. Şâfîi, burada da Kur’an ile Sünnet arasında benzer bir süreci işletmektedir. Şöyle ki; nasıl Allah Kur'an'da bir hükmü neshettiği vakit onun bedelini indiriyor, eski hüküm yenisiyle değiştiriliyor ve bu işlem bizim tarafımızdan biliniyorsa aynı şey Sünnet hakkında da geçerli olup bir sünnet neshedilmiş ise onu nesheden diğer sünnet de muhakkak bize nakledilmiş ve bilgimiz dahiline girmiş olmalıdır. Aksi takdirde "Belki de neshedilmiştir" denilmek suretiyle pek çok sünnetin zayi olmasına sebep olunacaktır. Bedel hükmü konulmamış hiçbir nesih işleminden bahsedilemez. ${ }^{32} \mathrm{Bu}$ yaklaşımın ehl-i hadis çevrelerinin rivayetlere önem

önce vârit idi, el kesmeyi emreden âyet sonra indi ve bu hadisi neshetti” deyip hırsız adı verilen herkese el kesme cezasını uygulamak ve yine "Sünnet seyyibe recm uygulanması şeklinde idi, sopa ile ilgili âyet bunu neshetti” deyip recim cezasını uygulamamak gerekir; halbuki yerleşik hükümler böyle değildir (bk. s. 233-34 [p. 647-51]).

29 Şâfiî, bunun ancak "cahillik"le savunulabilecek bir görüş olduğunu söyler (bk. erRisâle, s. 234 [p. 652]).

30 Şâfiî̀nin tercih kriterleri için bk. er-Risâle, s. 263-64, 276 (p. 722, 724, 757), 284-85 (p. $780-82)$.

31 er-Risâle, s. 108-109 (p. 324-26).

32 er-Risâle, s. 109 (p. 328). 
veren yaklaşımını güçlendirdiği ve onların rivayetler arasında yürüttükleri çalışmaları daha da değerli görmelerine yol açtığı ortadadır.

Kur'an’n Sünnet'teki bir hükmü neshetmiş ancak Sünnet' in bu doğrultuda getireceği nâsih uygulamanın bize rivayet edilmemiş olabileceği düşüncesine karşı çıkan Şâfiî, bunun Kur'an ile Sünnet arasındaki ilişkinin tersyüz edilmesine sebep olacağ 1 kanaatindedir. Bu kabul, hem Kur’an ile Sünnet arasında tesis edilen nesih ilişkisini zedeleyecek hem de bizi Sünnet' in mer'iyyeti hakkında nihâi mânada hiçbir zaman emin olamayacağımız bir yere sürükleyecektir. Aksini iddia etmek, Sünnet’e dair bilgilerimizi bütünüyle güvensiz bir noktaya taşımak anlamına gelecektir. Buradan hareket edecek birileri zâhirdeki farklılıklardan hareketle sünnetlerin Kur'an tarafından neshedilmiş olabileceğini pekâlâ iddia edebilir ${ }^{33}$ ve bir benzerini Kur'an'da bulmadıkları Sünnet hükümlerini redde kalkışabilirler. Neticede, beyan taksiminde sıralanan ilişki biçimlerinin çoğu geçersiz hale gelmiş olacaktır ki bu da Kur’an ile Sünnet arasındaki ilişkiyi neredeyse bütünüyle ihlal etmek anlamına gelir. Bu durumda mesela Kur'an'da yer alan mücmel bir hükümle ilgili sünnetler, âyetteki ifadelerle lafzı bakımından bir biçimde farklılaştıkları takdirde derhal reddedilecektir. ${ }^{34}$ Son tahlilde, Kur'an’n Sünnet'i neshedebileceğini kabul etmek, hem Hz. Peygamber' in teşrî faaliyetiyle uyuşmayacağı hem de buradan hareketle pek çok sünnetin hataen göz ardı edilmesine sebebiyet vereceği için doğru olamaz. ${ }^{35}$

Şâfiî, er-Risâle'de kaynaklar arası mahiyet farkı ile ilişki biçimlerini temellendirmesinin ardından, teorisini nesihle ilgili temsil değeri yüksek birtakım meselelere tatbik etmeye çalışır. Bu kısımda verdiği örnekler ve yaptığ açıklamalar, onun kaynaklar arası nesih ilişkisini ilkten reddettiğini ancak kaynağın kendi içinde başlayan bir nesih sürecine daha sonra diğer kaynağın müdahil oluşunu kabul ettiğini gösteriyor. Ancak verdiği örnekler, bu tespiti Kur’an’ın açıklanmasına Sünnet'in müdahil oluşuyla sınırlandırmayı gerekli kılmaktadır. Şöyle ki; Kur’an'da yer alan bir hüküm daha sonra neshe uğradığında Sünnet de bir şekilde bu nesih sürecine müdahil olup nihaî hükmün belirlenmesinde etkili olmaktadır. Nitekim bu örnekleri sunduğu bölümün başlı̆̆ı, "Bir Kısmına Kitabın, Diğer Bir Kısmınaysa Sünnet'in Delalet Ettiği Nâsih-Mensuh" şeklindedir. Mesela Allah beş vakit namazı farz kılmadan

33 Şâfiî burada alışveriş, zina, abdest ve hırsızlıkla ilgili önemli örnekler verir. Mesela "Allah alışverişi helal, faizi haram kıldı" (el-Bakara 2/275) âyeti gerekçe gösterilerek Hz. Peygamber'in yasaklamış olduğu alışveriş türlerinin mensuh hale geldiğinin iddia edilebileceğini ileri sürer (bk. er-Risâle, s. 111 vd. [p. 333]).

34 er-Risâle, s. 112-13 (p. 333).

35 Şâfiînnin izahları ve gerekçeleri için bk. er-Risâle, s. 221 (p. 605). 
önce farz bir namaz yükümlülüğü indirmişti. Önce gecenin yarısı veya ona yakın bir süre boyunca namaz kılmak emredilmiş (el-Müzzemmil 73/1-4), ardından güç yetirildiği kadar kılınması istenmişti (el-Müzzemmil 73/20). $\mathrm{Bu}$ âyetlerle birlikte teheccüt namazını emreden âyetin de (el-İsrâ 17/79) inmiş olması nihaî hükmün belirlenmesi hususunda bir işkâle yol açttğı için Sünnet'e başvurmak gerekti. İşte bu noktada Sünnet, daha önce bir kısmına bizzat Kur'an’’n delalet ettiği neshin eksik kalan kısmını tamamlamış ve beş vakit namaz dışındaki farz namazların mensuh olduğunu bildirmiştir. Şâfiî burada nihaî hükmün belirlenmesi noktasında Sünnet’e müracaat etmiş, farz olanın beş vakit namaz olduğunu herhangi bir âyete değil, Hz. Peygamber' in hadislerine dayandırmıştır. Bu durumu âyette kastedilen mânayı tespit için Sünnet'e başvurmak olarak takdim etse de nihayetinde nesih süreci hadislerle tamamlanmış olmaktadır. Ancak kendisi bunu nesih olarak kabul etmemekte ve "Bir kısmına Sünnet'in delalet ettiği nesih" diye adlandırarak söz konusu ilişkiyi delalet kapsamında görmektedir. ${ }^{36}$

Şâfiînnin Kur’an-Sünnet ilişkisine yönelik kabullerini nesih sürecinin bize aksedişi itibariyle ssrarla savunduğu bir diğer örnek, zina suçuna getirilen cezaî hükümlerin teşrî sürecidir. Bu konu da "Bir Kısmına Kitabın, Diğer Bir Kısmınaysa Sünnet'in Delalet Ettiği Nesih” olarak nitelediği kısımda yer alır. Şâfiînnin anlatımına göre zina hakkında inen ilk âyetler, fuhuş yapan kadınlara ölünceye kadar ev hapsi ve eziyet cezasını getiren Nisâ sûresinin 15-16. âyetleridir. ${ }^{37}$ Ardından bu cezayı neshedip yüz sopa cezasını getiren Nûr sûresinin 2. âyeti nâzil olmuştur. ${ }^{38}$ Bu iki hüküm, Kur'an’ın kendi içindeki nâsih-mensuhluk ilişkisini yansıtmakta iken Sünnet devreye girmiş ve yüz sopa cezasının bekârlara mahsus olduğunu göstermiştir. ${ }^{39}$ Yine Sünnet, yüz sopa cezasının hür bekârlar hakkında olduğunu, muhsan sınıfında yer alan kimseler hakkında mensuh kılındığını, recmin de hür evliler hakkında geçerli olduğunu göstermiştir. Hz. Peygamber' in Mâiz ve Eslemlinin kar1sı hakkındaki uygulamaları da bu yönde olmuş, onlar sopa cezasına çarptırılmaksızın recmedilmişlerdir. Şâfiî bu noktada şöyle der: "Önce Kitap,

36 Bk. er-Risâle, s. 113-17 (p. 336-45).

37 "Kadınlarınızdan fuhuş (zina) yapanlara karşı içinizden dört şahit getirin. Eğer onlar şahitlik ederlerse, o kadınları ölüm alıp götürünceye veya Allah onlar hakkında bir yol açıncaya kadar kendilerini evlerde tutun (dışarı çıkarmayın). Sizlerden fuhuş (zina) yapanların her ikisini de incitip kınayın. Eğer onlar tövbe edip ıslah olurlarsa, onları incitip kınamaktan vazgeçin. Çünkü Allah, tövbeleri çok kabul edendir, çok merhamet edendir."

38 "Zina eden kadın ve zina eden erkekten her birine yüzer değnek vurun."

39 "Allah onlara bir yol açtı; bekâr erkek ile bekâr kadın zina etmişse yüz sopa ve bir yıl sürgün cezasına, evli ile evli zina etmişse yüz sopa ve recm cezasına çarptırılacaktır" (Müslim, "Hudûd", 3). 
ardından Sünnet gösterdi ki köle zâniler bu hükmün dışındadır”. ${ }^{40}$ Teorisinin tatbiki için mühim bir örnek olarak gördüğü zina suçuyla ilgili cezaların değişkenliğine er-Risâle'de birkaç defa değinen Şâfîî, aslında ilgili hükümlerin teşrî sürecini izahta oldukça zorlanmıştır. Onun mushaf metninde yer almayan recm cezasını bir şekilde Kur'an’a taşıma çabası, gerek muhsan statüsünü tespit gerekse Hz. Peygamber ve sahabe devri recm uygulamalarına dair rivayetleri izah bakımından yorumun sınırlarını zorlayan bir gayret sarfetmesine yol açmış görünmektedir. ${ }^{41}$ Bu noktada dikkat çeken bir diğer husus, Şâfiî̀nin meseleyi "lafzı mensuh ancak hükmü bâki” diye ifade edilen nesih türüne değinmeden ele almış olmasıdır. ${ }^{42}$

Şafiî, Sünnet'e tanıdığı "nesih değil, delalet etme" işlevini, bu delilin bir uzantısı olarak gördüğ̈ icmâ üzerinden de aktararak ne kastetmiş olduğunu daha açık bir şekilde anlatmak istemiştir. Sünnet nasıl nâsih olmadığı halde Kur'an’ın kendi içinde gerçekleşmiş olan nesih süreçlerine delalet edebiliyorsa icmâ da Kur'an’ı neshedemediği halde ondaki nâsih ve mensuh hükümlere delalet edebilir. Bu itibarla Şâfiî, Sünnet'i nesih söz konusu olduğunda tıpkı icmâ gibi bir bilgi kaynağı olarak görmüş, bu kaynağg Kur’an'daki bir hükmü neshetme yetkisine sahip olmayan fakat bize neshi haber veren bir merci olarak takdim etmiş olmalıdır. ${ }^{43}$ Nitekim Kur’an ile Sünnet arasında nesih üzerinden kurduğu ilişkiyi, âm-hâs konusuna da yansıtmış; er-Risâle’nin Kur'an'da yer alan umum ve husus nitelikli ifadelerin nasıl anlaşılması gerektiğine dair bölümünde, "âm olarak nâzil olan ancak hâs olduğuna yalnızca sünnetin delalet ettiği” bir ifade türünden bahsetmiştir. ${ }^{44}$

40 er-Risâle, s. 133 (p. 383).

41 Şâfiînnin teorisinin izah gücünü yitirdiği yerler ve değerlendirmesi için bk. Burton, The Sources of Islamic Law, s. 146, 157-58.

$42 \mathrm{Bu}$ eksiklik, Şâfiî devrinde bu türden bir nesih tanımlamasına henüz ulaşılmadığını düşündürmektedir. Ayrıca ilgili hükümlerin teşrî sürecine dair el-Muvatta'da mezkûr birtakım meşhur rivayetlere hiç değinmiyor oluşu, dikkat çekilmesi gereken bir diğer husustur. Şâfiî bu konuyu ele alırken, Mâlik tarafından aktarılan "eş-şeyhu veş-şeyhatü ... Kur'an'dan bir âyetti” rivayetine başvurmazken görüşünü dayandırdığ 1 Ubâde hadisi ise Mâlik tarafından el-Muvatta'a alınmamıștır (bk. Burton, The Sources of Islamic Law, s. 146).

43 Şâfiî buna örnek olarak, nesih bağlamında en çok tartışılan meseleler arasında yer alan vasiyetle ilgili âyetleri zikreder. Şâfiînnin konuyu arzedişi ve kendi yaklaşımını meseleye tatbiki için bk. er-Risâle, s. 137-45 (p. 393-415).

44 Şâfiî, âyetin zâhirindeki hükmün değiştirildiği bu delalet türünü nesih değil, beyan kapsamında görmektedir (örnekler için bk. er-Risâle, s. 64-73 [p. 214-35]). Yani Şâfiî̀ye göre, Sünnet nasıl âm olarak nâzil olan bazı âyetlerin aslında hâs olduğunu gösteriyorsa nesihte de aynı ilişki geçerli olup Sünnet'in yaptığı bazı âyetlerin mensuh olduğunu göstermekten ibarettir (ayrıca bk. er-Risâle, s. 145-46 [p. 416-2o]). 
Delalet ve beyanla ilgili Kur'an üzerinden belirlediği esasları Sünnet’e de tatbik eden Şâfiî, ilk olarak Hz. Peygamber'in dili Arapça olduğu için hadisler arasında zâhiren teâruzların yaşanabileceğini dile getirir. $\mathrm{O}$, bu gibi teâruzların söz konusu olduğu sünnetleri öncelikle tasnif etme gereği duymuş ve "Bazı hadislerin zâhiri âmdır ve kendisiyle âm kastedilir", "Bazı hadislerin zâhiri âmdır ancak kendisiyle hâs kastedilir" diye ikili bir ayırıma gitmiştir. Bu ifade biçimlerinden kaynaklanan farklılıkların yanı sıra zâhirî teâruzlara yol açan daha başka durumlar da bulunmaktadır. ${ }^{45}$ Bu noktada dikkat edilmesi gereken en önemli husus, Hz. Peygamber'in bir sünnetini başka bir sünneti ile neshetmesi halinde bunu muhakkak açıklamış olacağıdır. Ancak sahabe bunu her zaman bütünüyle öğrenemeyebilir ve mesela nâsih hükmü rivayet ederken mensuh hükmü zikretmeyebilir. Fakat bu bilgi ümmetin tamamına gizli kalmaz ve araştırıldığ vakit hangi hadisin nâsih hangisinin mensuh olduğu muhakkak bulunur. ${ }^{46}$ Şâfî̉nin nesih bilgisinin hiçbir şekilde gizli kalmayacağına dönük ssrarı, herhangi bir rivayet bilgisi olmaksızın keyfî̀ nesih iddialarının önüne geçme gayesini yansıtır ve bu ssrar, hedefindeki muhaliflere yönelttiği genel tenkitlerin ruhuna da uygunluk arzeder. Şâfiî, nesih meselesini Kur’an-Sünnet ilişkileri için geliştirdiği teori içerisine taşımak suretiyle, bir taraftan Kur'an karşısında Sünnet’e hiç yer açmayan yahut bu yeri teâruz etmeme haliyle kayıtlayan çevrelere karşı konum alırken diğer yandan Hanefîler'in nasların sübut ve delalet biçimleri hakkında geliştirmiş oldukları kavramsal çerçevenin zorunlu sonuçlarından uzak kalınabilecek bir usulî zemin tesis etmiş oldu. Böylece o, ikinci şıktaki muarızlarına karşı bir bütün olarak Sünnet'in ve onu yansıttığını düşündügü hadislerin müdafaasını yerine getirmiş, ilk şıktaki muarızlarına karşı ise daha radikal bir konum alarak İslam toplumuna mal olmuş ve artık $f_{\imath} k_{\imath} h$ olarak benimsenmekte olan şerî̀ hükümler bütününü güvence altına almış oluyordu. ${ }^{47}$

45 Bunlar için bk. Şâfiî, er-Risâle, s. 213-15 (p. 575-82).

46 Şâfiî, er-Risâle, s. 214-15 (p. 582).

47 Şâfiî, Kur'an'da yer alan bir hükmün her hâlükârda esas alınması ve hiçbir surette terkedilmemesini savunanlara karşı, bu yaklaşımın mevcut fıkıh ahkâmının geçerliliğini tehdit edeceği endişesiyle karşı çıkar. O, er-Risâle’ye birçok yerde yansıyan, "Sünnet'in getirdiği ve insanların üzerinde icmâ ettiği” diye nitelediği hükümleri koruma altına almak istemiş ve böylelikle, üzerinde icmâ edilmiş hükümlerin tartışmaya açılmasına karşı önlem almıştır (bu hususta bir değerlendirme için bk. Burton, The Sources of Islamic Law, s. 98-100). 


\section{Kaynak-İçi Nesih Teorisinin Karşılaştı̆̆ İlk Tepkiler}

\section{a) Öğrencileri ve İkinci Nesil Şâfî̀ler'in Tavrı}

Şâfiînnin öğrencileri ve hitap ettiği ilk çevrelerde nesih teorisinin nasıl karşılandığı, teorinin açıklama gücü ve ikna ediciliği hakkında fikir verecek ilk vasattır. Şâfiî öncesinde gerek ehl-i re'y gerekse ehl-i hadis çevrelerinde Kur'an ile Sünnet'i böylesine ayıran ve aralarında hiçbir şekilde neshin cereyan etmeyeceğini savunan bir fakih yoktu. Peki, Şâfiîden sonra ne oldu, bu teori nasıl karşılandı, kimler tarafından benimsendi, ne gibi eleştirilere maruz kaldı? Şâfiînnin Bağdat ve Mısır'daki öğrencilerinin konuyla ilgili görüşlerini kendi metinlerinden öğrenme imkânından mahrumuz. Bağdat'taki öğrencilerin metinleri elimizde olmadığ gibi kendilerinden konuyla ilgili herhangi bir görüş nakledilmiş de değildir. Mısır'daki öğrencilerinin metinlerinde ise nesih problemine dair kendi görüşlerini yansıtan açıklamalara rastlanmaz. Büveytî, Muhtasar'ında yer verdiği ve içeriği itibariyle er-Risâle'deki fikirlerin özeti olarak görülebilecek "Bâb fỉr-Risâle" başlıklı bölümde, nesih hakkında birkaç cümle zikreder. Burada Şâfî̀nin görüşleri kısaca aktarılmış ve âyetler arasındaki nesih ilişkisini yansıtan birkaç örnek sıralanmıştır. ${ }^{48}$ Konuyu yalnızca Kur'an içinde yürüyen nesih üzerinden aktaran Büveytî, Şâfiî tarafından Sünnet'in Kur'an’’ neshedemeyeceğinin delili olarak ileri sürülen âyetleri zikretmekle yetinir ve ilave herhangi bir açılama yahut değerlendirmeye yer vermez. ${ }^{49}$ Müzenînin günümüze intikal eden eserlerinde de neshe dair teorik açıklamalara rastlamıyoruz. Ancak Müzenî ve Rebî‘ $b$. Süleyman el-Murâdîye Mısır'da öğrencilik yapmış olan Muhammed b. Nasr el-Mervezî, bu konuda kayda değer bir şahitlikte bulunarak kaynaklar arası nesih meselesinde ashabının Şâfiî ile hemfikir olduklarını nakleder. ${ }^{50}$

Şâfiînnin öğrencilerinden ders alan, onlardan Şâfiînnin eserlerini temin eden ve mezhep kaynaklarında ikinci nesil Şâfiî fukahası olarak gösterilen isimler, kaynaklar arası nesih meselesinde Şâfiî̀yi desteklememektedir. Pek çoğu Ehl-i hadis fakihi olan bu isimlerin mezhebi aidiyetleri de tartışmaya açıktır. Nitekim fikhî mânada Şafiî̀ye intisapları zayıf olan bu isimlerin nesih meselesinde onun görüşünü sahiplenmemeleri şaşırtıcı değildir. Mesela İbn Huzeyme, Taberî, İbnü'l-Münzir ve Mervezîden oluşan ve mezhep

48 Bk. Büveytî, Muhtasar, s. 1050. Örneklerin ikisi er-Risâle'de geçmekle birlikte, Nûr sûresinin 3. âyeti ile 32. âyeti arasındaki nesih meselesi el-Üm'den alınmış görünmektedir. Elimizdeki er-Risâle nüshasında bu örnek yer almıyor, ancak Büveytînin kendi nüshasında bu meselenin de mezkûr olduğu düşünülebilir.

49 Bk. Büveytî, Muhtasar, s. 1055-56.

50 es-Sünne, s. 442, 576 . 
kaynaklarında "dört Muhammedler" olarak anılan âlimler grubundan hiçbirisi bu konuda Şâfiî ile aynı görüşü paylaşmamıştır. ${ }^{51}$

Mervezî, es-Sünne'sinde ulemânın üzerinde ittifak edip etmemesi bakımindan Sünnet'i taksim etmiş, amele dair sünnetler içerisinde ihtilafa konu olan bir tür olarak nesihle ilgili rivayetleri değerlendirmiştir. ${ }^{52}$ Kur'anSünnet ilişkisinin ele alındığı kitabın ikinci bölümünde ağırlıklı olarak bu başlık üzerinde durulur. Çok sayıda örnek üzerinden iki tarafın görüşlerini arzeden Mervezî, kendi kanaatini açıkça belirtmemekle birlikte, kullandığ1 bazı ifadeler ve kimi eleştirileri nesih konusunda Şâfiî̀ye katılmadığını göstermektedir. Bu kanaati, zina haddinin teşrî sürecini ele aldığı örnekte açığa çıkmakta olup Şâfî̀nin ilgili âyet ve hadisler arasında kurduğu irtibatları zayıf bulan Mervezî, onun ulaştığı sonucun nesih hakkında benimsediği ilkeyle çeliştiğini düşünür. ${ }^{53}$ Mervezînin ifadeleri, Sünnet'in Kur'an’’ neshini kabul ettiğine işaret etmektedir. Bu tartışmanın yürütüldügü daha pek çok örneği herhangi bir değerlendirmede bulunmadan aktaran Mervezî, kitabın sonlarına doğru dile getirdiği bir eleştiriyle yine Şâfiîden farklı düşündügünü gösterir. Mervezî, Sünnet'in Kur'an’ı neshedemeyeceğini söylemenin Sünnet'in konumunu gereğince takdir edememekten ileri geldiği kanaatindedir. $^{54}$

İbn Huzeyme Sahîh'inde, Kur'an-Sünnet ilişkisinin beyana dair boyutlarında Şâfiînnin geliştirdiği anlayışa muvafık düşen bir yaklaşıma sahip iken, nesih konusunda ondan ayrilır. Eserinde muhtelif vesilelerle neshe değinen İbn Huzeyme’nin bazı meseleleri ele alış şekli, nesih hakkındaki kanaatlerini de yansıtmaktadır. ${ }^{55}$ Mesela kıblenin tahvili meselesinde "Namaz için Kâbe’ye

51 Bu âlimler grubunun Şâfiî̀ye intisaplarının mânası ve mezhep içerisindeki yerleri hakkında bk. Okuyucu, Şâfî̀ Mezhebinin Teşekkül Süreci, s. 319-403.

52 Mervezînin Sünnet taksimi için bk. es-Sünne, s. 262-78.

53 Mervezînin ifadeleri şu şekildedir: "Şâfiî, bu meselede Kitabın Sünnet ile neshini kabul etmiş olmaktadır. Zira muhsan olmayanların celde ile birlikte sürüleceklerini söylüyor. Celde, Kitap ve Sünnet ile sabit olduğu halde sürgün sadece sünnet ile sabittir. Yine muhsanlara recimle birlikte celde uygulanacağını da söylemiştir ki celde Kitap ve Sünnet ile sabit olduğu halde recim sadece Sünnet ile sabittir. Şâfiî, evliler hakkındaki ilk cezanın recim ve sürgün olduğunu söyleyip Hz. Peygamber'in daha sonra muhsanlardan celdeyi kaldırdığını, recmi ibka ettiğini de kabul eder. Yine, âyetin nüzulü esnasında sabit olan, muhsanlar hakkındaki celdenin daha sonra Hz. Peygamber tarafından kaldırıldığını da kabul etmektedir. Dolayısıyla celdenin sünnetle mensuh olduğu ortadadır" (Mervezî, es-Sünne, s. 603-604).

54 Mervezî, çapraz nesih hakkında Şâfiî̀ ile hemfikir olan Ebû Sevr'in görüşünü naklettikten sonra onu hedef alarak tenkitte bulunur. Bu noktada Şâfiînnin öne çıkardığ 1 üzere Sünnet'i hikmet olarak nitelemesi de kayda değer bir husustur (bk. es-Sünne, s. 678-79).

55 Mesela mücmelin tebyini ile neshin farklı şeyler olduğuna değinen İbn Huzeyme, bunların birbirine karıştırılmaması gerektiğine işaret eder (Sahîh, I, 34), mütevatir 
yönelme emrinin gelişi ve Beytülmakdis’e yönelme emrinin neshi” diye bir bab açar. ${ }^{56}$ Beytülmakdis'e yönelme emrinin ne şekilde sabit olduğu hususu tartışmalı olmakla birlikte, Kur’an’da bu yönde bir emir bulunmadığına göre uygulamanın gayri metlûv bir vahye dayanmış olsa bile Hz. Peygamber' in Sünneti ile sabit olduğu açıktır. İbn Huzeyme, Kur’an’n Sünnet'i neshini kabul ettiği için böyle bir bab açabilmiştir. ${ }^{57}$ İbn Huzeyme, Kur'an ve Sünnet' in kendi içlerinde nâsih-mensuh olduklarını zaten kabul etmekte ve Kur'an’n nüzulü ve Hz. Peygamber'in teşrî süreci boyunca ibadetlerle ilgili kimi değişiklikleri nesihle açıklamaktadır. ${ }^{58}$ Sünnet'in Kur’an’ı neshine dair açık bir ifadesine rastlanmamakla birlikte, Kur'an’n Sünnet'le sabit birtakım uygulamaları neshettiğine değinmesi, Şâfiînnin nesih anlayışını benimsemediğini göstermektedir. Dört Muhammed'den üçüncüsü olan Taberî, tefsirinde nesih anlayışını açıkça yansıtmış ve kaynaklar arasında neshi kabul ettiğini gösteren açıklamalarda bulunmuştur. Erken dönem nesih anlayışının gelişiminde hususi bir yere sahip olan Taberî, hem Kur'an’ın Sünnet'i hem de Sünnet'in Kur'an’ı neshini kabul eden bir âlimdi. ${ }^{59}$

haberlere dayanan hükümlerin, hakkında ihtilaf edilmiş hadislerle neshedilemeyeceğini belirtir (Sahîh, III, 55), Hz. Peygamber'in emri ile sabit bir hükmün onun daha sonraki sükûtuyla neshedilmiş olmadığını, bu emrin sâkıt olduğuna dair açık bir ifadesi olmadıkça hükmün sürdügünü dile getirir (Sahîh, IV, 81).

56 Sahîh, I, 223.

57 İbn Huzeyme’nin kanaatinin bu yönde olduğunu gösteren bir diğer örnek, namazda konuşma meselesi olup rivayetlerin sunduğu bilgiye göre ilk zamanlarda namazda konuşmak mübahtı ve namaza tesir etmemekteydi. Ancak "Allah'a gönülden boyun eğerek namaza durun" mealindeki âyet (el-Bakara 2/238) nâzil olunca hüküm değiști ve namazda konuşmak bu ibadeti bozan, yasaklanmış bir eylem haline geldi (Sahîh, II, 34). Gayri metlûv vahiyle yahut Sünnetle sabit olup Kur'an ile neshedilmiş bir diğer hüküm, müslümanların ilkin oruç tutmak ile fakir doyurmak arasında muhayyer bırakılmış olmalarıdır. Bu hüküm, orucun farziyetini bildiren Bakara sûresinin 185 . âyetiyle neshedilmiștir Yine Ramazan gecelerinde cinsî münasebetin önce haramken daha sonra mübah kılınışı da böyledir (bk. Sahîh, III, 200).

58 Bk. Sahîh, I, 27, 112, 301, 315-19; II, 171; III, 249.

59 Taberî̀nin nesih anlayışı için bk. Boynukalın, İbn Cerîr et-Taberî, s. 107-14. Erken dönemde Şâfiî fıkıh çevresiyle irtibatı bulunan bir diğer isim olan Muhâsibî, konu hakkındaki görüşünü açıkça ifade etmese de Sünnet'in Kur'an tarafından neshedildiğini kabul ettiğine delalet edecek bazı ifadelere yer vermiştir (Muhâsibî̉nin ve İbn Kuteybe'nin konuyla ilgili görüşlerinin tahlili için bk. Melchert, "IX. [III.] Yüzyıl Boyunca Nesih", s. 201-22). Yine erken dönem Şâfîi çevresinin bir mensubu olarak görülebilecek Ahmed b. Hanbel'in nesih hakkındaki düşünceleri tartışmaya konu olmuş, kendisinden farklı görüşler nakledilmiştir. Hanbelî usulcü Tûfî, imamlarının Kitabın Sünnet'i neshini kabul ettiği ancak Sünnet'in Kitabı neshine karşı çıktığını belirtir (bk. Tûfî, Şerhu Muhtasarirr-Ravza, II, 315-25). 


\section{b) İlk Ciddi Kırılma: İbn Süreyc ve Öğrencilerinin Yaklaşımları}

Şafiî mezhebinin usul düşüncesinin gelişiminde önemli dönüm noktalarından birini temsil eden ve üçüncü nesil Şâfî̀ler arasında akla ilk gelen isim olan Ebü'l-Abbas İbn Süreyc, geliştirdiği ayırımlar ve kabulleriyle mezhebin nesih anlayışının şekillenmesine ciddi katkı sunmuştur. Günümüze intikal eden iki metninden biri olan el-Vedâi in usulle ilgili son kısmında yer verdiği "Bâbü zikri’n-nesh" başlı̆̆ındaki cümleleri ${ }^{60}$ ve sonraki kaynaklarda kendisine atfedilen görüşler, İbn Süreyc'i diğer pek çok konuda olduğu gibi nesihte de önemli açılımlar sağlamış bir fakih-usulcü olarak öne çıkarır. ${ }^{61}$ İbn Süreyc'in Kur'an ile Sünnet arasındaki nesih ilişkisine dair görüşleri, Şâfiî̉nin yaklaşımından kısmen ayrılması ve mezhep çevresinde zamanla sınırları genişleyerek belli bir dereceye kadar kabul görecek olan muhalif görüşe kapı aralaması bakımından tarihî önemi haizdir. Onun yaklaşımı, ilerleyen dönemlerde tartışmaların seyredeceği mecrayı belirleyecek bir ayırım barınd1rır. Bu ayırımı tam anlamıyla benimsemediğine varacak kadar nakiller söz konusu olsa da İbn Süreyc'in konuyu taşıdığı zemin mezhep içerisinde yeni açlımların sağlanmasına imkân vermiştir. Onun çapraz nesih meselesi bakımından sağladığı en önemli katkı, konuyu aklî imkân - şerîi imkân ayırımına taşımasıdır.

el-Vedâi ín nesihle ilgili bölümünde meseleye Kur'an’ın Sünnet tarafından neshi, Sünnetle ilgili bölümünde ise nâsih-mensuh sünnetler çerçevesinde değinen İbn Süreyc, burada Şâfiî̀nin görüşünü sürdürüyor görünmektedir. Şâfiî kaynaklardaki nakillerse konuya yaklaşımının önemli farklılıklar taşıdığına işaret eder. Hemen bütün kaynaklar, nesihle ilgili farklı bir görüşü dillendiren ilk Şâfiî̀nin İbn Süreyc olduğunda -ikinci neslin mensubiyetleri tartışmalı isimleri dışarıda tutulacak olursa- müttefiktir. ${ }^{62}$ Fiilen gerçekleş-

6o el-Vedâi in usulle ilgili son kısmı için bk. Okuyucu, "Shâfi'î Usûl Thought in Late Third-Century Ah", s. 87-133.

61 Görebildiğimiz kadarıyla tilavet-hüküm ayırımı bakımından neshi tasnif eden ilk Şâfiî fakihi İbn Süreyc'dir. Onun yaptığı; a) Hükmün neshedilip lafzın bâki bırakılması, b) Lafzın neshedilip hükmün baki bırakılması, c) Lafızla hükmün bir arada neshedilmesi şeklindeki üçlü ayırıma, Şâfiî ve ashabının metinlerinde rastlamıyoruz. İbn Süreyc'in Şâfiî sonrasında gelişen ve en-Nâsih ve'l-mensûh literatüründe de yer bulan tasnifi Şâfiî usul düşüncesine taşıdığı görülüyor. Bu üçlü tasnife Ebû Ubeyd (ö. 224/838) ve Nehhâs'in (ö. 338/950) eserlerinde rastlanmaktadır (Ebû Ubeyd, en-Nâsih ve'l-mensûh s. 14-17; Nehhâs, en-Nâsih ve'l-mensûh, s. 57-61). Nitekim İbn Süreyc'in öğrencisi Ebû İshak el-Mervezî (ö. 340/951) bu tasnifi daha da ileri taşıyacak ve neshi vuku şekli bakımından altıya ayıracaktır (Zerkeşî, el-Bahrü'l-muhît, IV, 103-107), İbn Süreyc'in üçlü tasnifi usule taşıyışı hakkında bk. Okuyucu, "Shâfi'î Usûl Thought in Late ThirdCentury Ah", s. 104.

62 Mervezînin yukarıda da nakledilen tanıklı̆ğ için bk. es-Sünne, s. 442, 576. 
memiş olsa dahi Kur'an’n Sünneti neshinin mümkün olduğunu düşünen İbn Süreyc, Sünnet' in Kur'an’ı neshi hakkında da benzer bir yaklaşıma sahiptir. Mütevâtir sünnetin Kur'an’ı neshedebileceğini ancak bu tarz bir neshin şer'an vâki olmadığını savunan İbn Süreyc'e göre, Sünnet'in Kur'an’’ neshini kabul edilemez kılan husus akıl değil, fiilî durumdur ve de bunu engelleyecek bir şer î delil söz konusu değildir. ${ }^{63}$

Şafiî usul eserlerinin genel anlatımının dışına çıkan Zerkeşî, İbn Süreyc'in öğrencilerinin kaleme aldığ la Şâfiî arasında herhangi bir farklılık bulunmadığını ileri sürer. Onun Ebû İshak el-Mervezînin (ö. 340/951) nesihle ilgili eserinden yaptığı nakle göre, İbn Süreyc önceleri Şâfî̀nnin çapraz neshe karşı çıkışını, "Bu tür bir nesih vâki olmadığ 1 için kabul etmemiştir” diye yorumlarken zamanla kanaati değişmiş ve o da imamı gibi bunun mümkün olmadığını savunmaya başlamıştır. $\mathrm{Bu}$ kanaat değişikliğinin sebebi, Bakara sûresinin 106. âyetinin anlamı ${ }^{64}$ üzerindeki teemmülüdür. İbn Süreyc'e göre bu âyeti, getirilen hüküm üzerinden anlamak ve "daha hayırlı" ile kastedilenin yeni hüküm olduğunu, bunun da Sünnet ile gelebileceğini kabul ederek Kitabın Sünnetle neshine kapı aralamak yanlış olur. Zira ilk emri veren de ikincisi ile onu değiştiren de Allah'tır ve Kur’an ile sabit bir hükmün başka kaynaklarca değiştirileceğini söylemek mu'ciz Kitaba müdahalede bulunmak anlamına gelecektir. Nitekim âyetin, Allah’n her şeye kadir olduğunu bildiren son kısmı da bu anlamı teyit etmekte olup mu'ciz olan âyetlerle sabit hükümlerin yerini ancak mu'ciz olan âyetlerle sabit olacak hükümler alabilecektir. "Daha hayırlı olan"ın getirileceği söylenerek "tilaveti daha çok sevap kazandıranın getirilmesi" kastedilmiş olur ki her iki durumda Kur'an’’n yerine geçen yine Kur'an olacaktır. ${ }^{65}$ Zerkeşî, İbn Süreyc'in görüşünün yanlış aktarıldığından şikâyet eder ve kendi naklini onun bir öğrencisi tarafından kaleme alınan metne dayandırmak suretiyle uyarida bulunur.

İbn Süreyc'in gerçekte neyi düşündüğü tartışması bir yana, onun öğrencileriyle birlikte artık mesele aklî imkân - şerî imkân ve vuku bağlamında bahse konu olmuş ve böylelikle mezhep çevresinde ileri sürülebilecek yeni yorumların önü açılmıştır. İbn Süreyc'den sonra Kur'an’n Sünnet ile neshini kabul etmeyen Şâfiî usulcüleri arasında bunu engelleyen unsurun akıl

63 Mâverdî, el-Hâvi'l-kebîr, XVI, 78-79, 104; Cüveynî, et-Telhîs , II, 514-15; Şîrâzî, et-Tebsıra, s. 264; Âmidî, el-İhkâm, III, 153; bu hususta ayrıca bk. Okuyucu, "Shâfi'î Usûl Thought in Late Third-Century Ah", s. 106.

64 "Biz herhangi bir âyetin hükmünü yürürlükten kaldırır veya onu unutturur (ya da ertelersek), yerine daha hayırlısını veya mislini getiririz. Allah’n gücünün her şeye hakkıyla yettiğini bilmez misin?"

65 Zerkeşî, el-Bahrü'l-muhît, IV, 113-14. 
mı yoksa şer' mi olduğu tartışması başlamıştır. Başta Ebû İshak el-Mervezî olmak üzere Şâfiî fukahasının çoğunluğu, fiilî durumdan hareket ederek engelleyici unsurun şer ${ }^{`}$ olduğunu savunurken Ebû İshak el-İsferâyînî (ö. 418/1027) ve Abdülkāhir el-Bağdâdînin de (ö. 429/1037) içinde bulunduğu bazı kelamcı Şâfiîler bunun aklen imkânsız olduğu görüşündedir. ${ }^{66}$ Kur'an’n Sünnet ile neshine fiilî durumdan hareketle karşı çıkan yorum, İbn Süreyc'in öğrencisi olan er-Risâle şârihi Ebû Bekir es-Sayrafî (ö. 330/941) üzerinden yayılma imkânı bulmuş olmalıdır. Sayrafî, Şâfiînnin mevcut delillerden hareketle Kur'an’ın Sünnet ile neshine karşı çıtığını, yoksa Kur'an ile sabit bir hükmün Sünnet ile ortadan kaldırılmasını muhal görmediğini ifade ederek engelleyici unsurun şer ${ }^{`}$ olduğu görüşünü mezhep imamına nispet eder. Kur'an’’n Sünnet ile neshine kendisi de kesin bir şekilde karşı çıkan Sayrafìye göre imkânsızlı̆̆ın kaynağı, böyle bir şeyin hiç yaşanmamasıdır. ${ }^{67}$ Sayrafî, bu bağlamda en çok tartışılan meselelerden biri olan vasiyetle ilgili hükümlerin neshinde nâsihin Kur'an olduğunu, Sünnet'in yalnızca yeni hükmü beyan ettiğini belirtir. ${ }^{68}$ Şîrâzî ve İbn Berhân gibi bu konuda Şâfiî̀ye yakın duran usulcülerin, "Kitabın Sünnet ile neshi sem' açısından câiz değildir" diyerek benimseyip sürdürdükleri yorum, Sayrafînnin bu izahına dayanmaktadır. Burada hatırda tutulması gereken en önemli husus, meselenin bizzat Şâfiî tarafından aklî-semî ayırımından hareketle ele alınmadığı, bunun daha sonraki fakihlerce geliştirilmiş bir yorum olduğudur. ${ }^{69}$

Sünnet'in Kur'an ile neshi hususunda Şâfiî̀nin er-Risâle'deki açık ifadelerine rağmen mezhep âlimleri bunu da tartışmaya başlamış ve belli bir tarihten itibaren bu konuda Şâfiîye iki farklı görüş nispet edilir olmuştur.

66 Aklen imkânsızlı̆̆ı savunan isimler arasında Muhâsibî, Abdullah b. Sa‘d, Kalânisî, Zâhirîler ve bir rivayete göre Ahmed b. Hanbel de yer alır. Diğer taraftan Ebû İshak eş-Şirâzî de şer'an imkânsızlığı savunur (bk. Zerkeşî̀, el-Bahrü’l-muhît, IV, 111; Şîrâzî, Şerhu'l-Lüma', I, 501).

67 Onun yorumuna göre Şâfiî̀, “Kur’an’ın Sünnet ile neshi câiz değildir” derken “İhramlı kişinin evlenmesi câiz değildir” cümlesindeki anlamı kastetmiştir. Yani aklen mümkün olmakla birlikte, şer'an doğru değildir (bk. Zerkeşî, el-Bahrüll-muhît, IV, 114).

68 Zerkeşî, el-Bahrü’l-muhît, IV, 115.

69 Aklî imkân etrafındaki tartışmalar IV. (X.) asrın ilk kısmında başlamış; kimi usulcüler Şâfiî̀nin bazı ifadelerinden hareketle aklî-sem î̀ ayırımını geriye doğru yansıtarak imamlarına nispet etmeye çalışırken kimileri imamın çapraz neshe hem aklen hem de semán karşı çıkmış olduğunu iddia etmişlerdir (Zerkeşî, el-Bahrü̉l-muhît, IV, 110-16). Zerkeşî, aklî imkânsızlığın da ileri sürülmesi halinde baş gösterecek kimi problemler ve Mu'tezilî kabullere götürebilecek çağrışımlarından ötürü Şâfiî̀ye yapılacak nispetin semî̀ imkânsızlıkla sınırlı kalmasından yanadır. Zira Şâfiî görüşünü aklî delillerle değil, şer'î delillerle gerekçelendirmiștir. Bu konuda Şâfiî̀yi destekleyen Su'lûkî, Ebû İshak el-İsferâyînî ve Ebû Mansûr el-Bağdâdî de Şâfiînnin çapraz neshe şer'an karşı çıktığını belirtmişlerdir (bk. Zerkeşî, el-Bahrü’l-muhît, IV, 113). 
Ebû İshak el-Mervezî, Şâfiînnin Sünnet'in Kur'an ile neshini kabul etmediğini sarahaten belirtmesine karşın bazı ifadelerinin yorumlanmasıyla kendisine ikinci bir görüş daha atfedildiği tespitinde bulunur. $\mathrm{Bu}$ yorum zamanla nakle dönüşecek ve Şâfiî̀ye iki farklı görüş nispet edilecektir. ${ }^{70}$ Mâverdî, $e l-$ Vedâi 'de bu meseleye değinmeyen İbn Süreyc'in Şâfiî̀ye muhalif kaldığını ve Kur'an’’n Sünnet'ten üstün oluşu gerekçesiyle bunu kabul ettiğini nakleder. ${ }^{71}$ İfadelerinden anlaşıldığı kadarıyla Ebû İshak el-Mervezî de bunu savunmakta, Sayrafî ise Şâfiînnin görüşünün kesinlikle bu doğrultuda olduğunu iddia etmektedir. Her iki görüş birçok Şâfiî usulcü tarafından benimsenirken hangi kesimin çoğunluğu teşkil ettiği de tartışmalı hale gelmiştir. ${ }^{72}$

İbn Süreyc'in öğrencileri, Şâfiî̀nin nesih teorisini geliştirirken taşıdığ 1 endişelerin farkındaydılar. Onlar aynı endişeleri İbn Süreyc'in de taşıdığını naklederek beyan ile neshi karşı karşıya getirmeyen bir yorum geliştirme çabasında oldular ${ }^{73}$ ve Şâfiî̀nin bazı kabullerini terkederken bu endişeleri ihlal etmediklerini gösteren açıklamalar yaptılar. Ebû İshak el-Mervezî, Şâfiînnin kaynak-içi nesih anlayışını izah ederken onun esas kaygısının nesih ile beyanın birbirine karıştırılmaması olduğunu açıkça dile getirir:

"Şâfiî,, hem kadim hem de cedit er-Risâle'de Hz. Peygamber'in sünnetinin ancak bir başka sünnet ile neshedileceğini ve Kitabın Sünnet'i neshetmediğini, yine Sünnet'in de Kitabı neshetmediğini açıcça dile getirmiştir (nassa). Hz. Peygamber'in sünnetinin olduğu bir hususta Allah’n kitabı bir hüküm getireceğinde, O’nun sünnetini nesheden ikinci bir emir gelir ki bu surette sünnetin neshini Hz. Peygamber bizzat üstlenmiş olur. Bu şekilde bir sünnetin gelmesinin sebebi, beyan ile neshin birbirine karışmaması ve böylelikle

7o Zerkeşî, el-Bahrül-muhît, IV, 118. Zerkeşî ikinci görüşü üreten yorumun isabetsiz olduğunu, Şâfiînnin ifadelerinden böyle bir anlamın çıkarılamayacağını söyler (el-Bahrülmuhît, IV, 120). Aralarında Cüveynînin de bulunduğu birçok Şâfiî usulcü -kendi kanaatlerinin o yönde olduğunu hatırda tutacak olursak- Şâfiî̀ye cevaz görüşünün nispet edilmesini daha doğru bulurlar.

71 Mâverdî, el-Hâvi'l-kebîr, XIII, 189; Zerkeşî, el-Bahrü'l-muhît, IV, 118. Sübkî, Şâfiî̀ye ikinci bir görüş isnat edilişini er-Risâle'deki ifadelerin doğru anlaşılmamasına bağlar. Geçmiş bir sünnet ile sabit hükmün neshedilme sürecine dair Şâfiînnin ortaya koyduğu anlatım açık olmasına karşın bazı usulcüler bunu farklı yorumlamış ve Şâfiînnin Kur'an’ın Sünnet'i neshini kabul ettiğini ileri sürebilmişlerdir (bk. Sübkî, el-İbhâc, II, 249). İsnevî de Beyzâvînnin metnini şerhederken kullanılan ifadeyi uygun bulmaz, bu ifadelerin sanki Şâfiî̀ye ait iki farklı görüş varmış gibi düşündürdügünü ancak bunun doğru olmadığını dile getirir (bk. Nihâyetüs-sûl, s. 497).

72 Bk. Zerkeşî, el-Bahrü’l-muhît, IV, 118. Burada aktarılan bir bilgiye göre İbn Berhân, benimseyenleri arasında Kadı Ebü't-Tayyib ve Cüveynî gibi usulcülerin de bulunduğu bu tür neshin mümkün olduğu görüşünü çoğunluğa nispet ederken Râfiî̀, Şâfîiler'in ekserisinin aksi görüşte olduğunu savunur (bk. Zerkeşî, el-Bahrü̉l-muhît, IV, 118).

73 Bk. Zerkeşî, el-Bahrül-muhît, IV, 121-23. 
Hz. Peygamber'in Kur'an’n zâhirine muhalif düşecek bir sünnetinin varlığını kabule ve Kur'an’ın nâsih sayılmasını gerektirecek bir duruma mahal vermemektir. Veya zâhiri Kur’an'a muhalif düşen bir sünnetin Kur’an’ı neshedeceği bir duruma mahal vermemektir. Aksi takdirde bu durum sünnetlerin çoğunun elimizden çıkıp gitmesine vesile teşkil edebilir." ${ }^{34}$

Mervezî, Şâfiî̀nin bu hassasiyetini paylaşmakla birlikte, aslında onun ulaştığı çözümlerin çoğu yerde Kur'an’n Sünnet’i neshi sonucuna götürdüğüne dikkat çeker. O, tartışmaya konu olan meselelerin incelenerek nesihden veya beyandan hangisi ile çözüme gidilebiliyorsa o yönde karar vermek gerektiği kanaatindedir. Mesela âmmın tahsisine başvurmak suretiyle mesele izah edilebiliyorsa sünnetin önce veya sonra olmasının bir anlamı olmayacaktır. Zira sünnetin önce, âm nitelikli âyetin sonra vârit olması halinde âm nitelikli kelam esas alınacak ve bu beyan olacak, sünnetin daha sonra vârit olması halinde ise âm nitelikli âyet bu sünnetle tefsir edilmiş olacak ve bu yine beyan olarak kabul edilecektir. ${ }^{75}$ Şu da var ki Mervezî, hükmü kaldıran Kur'an âyetine bir sünnet eklendiğinde her hâlükârda önceki sünnetin mensuh hale geldiğini ve durum böyle olunca nesihle beyanın karışma korkusunun ortadan kalktığını söyler. Bu tehlike ortadan kalktığında ise gerçekte nâsih olanın âyet mi yoksa hadis mi olduğunun bir önemi kalmamaktadır. Mervezînin, "Aslında Kur'an ile Sünnet' in birbirini neshetmediğine dair elimizde açık bir delil yoktur" şeklindeki cümlesi tartışmaya dair düşüncelerinin özeti gibidir. O, her ne kadar çapraz nesih meselesinde Şâfiî̀yi desteklemeye çalıssa da onun sunduğu bütün örnekleri tartışlabilir ve aksi görüşü de kabul edilebilir bulmuştur. ${ }^{76}$

Kur'an’ın Sünnet'i neshine dair daha farklı bir yoruma ulaşan Sayrafî, aslında Şâfî̉nin Sünnet'in Kur’an ile sabit bir hükmü kaldırmasını imkânsız bulmakla birlikte, Kur’an’nn sünnet ile sabit bir hükmü kaldırmasını mümkün gördüğ̈nü ve hatta bunu bizzat tespit etmiş olduğunu söyler. Onun ifadelerine göre, Şâfiî bunun farkına varmış ancak bu tarz bir neshin muhakkak nâsih konumundaki yeni bir sünnetin gelmesiyle tahakkuk edeceğini ileri sürmüştür. Aksi takdirde Kur'an'da yer alan âm nitelikli âyetler Hz. Peygamber'in beyanlarını geçersiz kılardı. Yani Allah sünnet ile sabit bir hükmü kaldırmak istediğinde bunu Hz. Peygamber'e bildirmiş ve o da bunun gereğince eski

74 Zerkeşî, el-Bahrü’l-muhît, IV, 121.

$75 \mathrm{Bu}$ durumda âyetin neshedilmiş olduğunu düşünenler, mücmel karşılığında müfesser ve nasla sabit hükmün terkini istemiş olurlar. Onlara, bunun $\mathrm{Hz}$. Peygamber'in vazifesi kabilinden bir beyan olduğu ve muhtemel lafızlar karşısında nassın terkedilemeyeceği söylenerek cevap verilir. Mervezînin bu değerlendirmelerinin bir kısmının, hocası İbn Süreyc’e dayandığı anlaşılmaktadır (bk. Zerkeşî, el-Bahrül-muhît, IV, 121-22).

76 Zerkeşî, el-Bahrül-muhît, IV, 123. 
sünnetin mensuh olduğunu bildiren yeni bir sünnet ihdas etmiştir. Hükmü kaldıran Allah’ın kelamı, bunu gösterense Hz. Peygamber'in sünnetidir. ${ }^{77}$ Sayrafî, kaynaklar arasında yürüyen neshe dair sunduğu bir taksimle yorumlarını daha da ileri taşır. O, “Hz. Peygamber'in getirdiği hükümlerin Kur’an tarafından kaldırıldığı" durumları, iki hüküm arasında muvafakat ihtimalinin olup olmamasına göre ikiye ayırır. ${ }^{78}$ İki kaynak arasındaki her tür karşıtlığ 1 nesih olarak görmeme kaygısından kaynaklanan bu ayırım, neticede Şâfî̉nin yaklaşımını sınırlandırmış olması açısından önemlidir. Mervezî ve Sayrafînnin bu açıklamaları, Şâfiî̀nin teorisinde beyan ile neshin birbirinden özenle ayrılmış olduğuna yönelik vurgular taşıması bakımından önem arzeder. $^{79}$

Şâfiî̀nin yaklaşımının mezhep içerisinde bütünüyle sahiplenilmesinin imkânsız hale gelmesiyle, IV. (X.) asrın ortalarından itibaren bazı tevil arayışları baş gösterdi. Çapraz nesih konusunda Şâfiî̀yi doğrudan tenkit etmeyi uygun bulmayan kimi âlimler, aslında kendisine katılmasalar da imamlarının yaklaşımını bir şekilde tevil etme gayretinde oldular. Şâfiînnin otoritesine halel gelmemesi için geliştirilen bu tevillerden biri şöyledir: Şâfii çapraz neshe karşı çıkarken aslında Hz. Peygamber’in içtihat ile hüküm koyma yetkisinden hareket etmiştir. Şöyle ki; Hz. Peygamber’in kendi içtihadı vasıtasıyla Kur’an’in nassına muhalif bir beyanda bulunması söz konusu olmadığına göre, diğer müçtehitlerin içtihatlarından farklı olarak müslümanlar açısından bağlayıcılık arzeden bu içtihadın mutlaka şer'î bir dayanağı bulunmaktadır. Onun içtihatta bulunurken Kitabın neshini gerektirecek bir karar alması ve

77 Zerkeşî, el-Bahrüll-muhît, IV, 122-23.

78 Kıblenin tahvili gibi muvafakat ihtimalinin olmadığ 1 durumlarda Hz. Peygamber sonraki uygulamasıyla Kur’an’ın getirdiği yeni hükme imtisal etmiştir. Vasiyeti ve mirası düzenleyen âyetlerde olduğu üzere muvafakat ihtimalinin bulunduğu durumlarda ise nesihten ancak Hz. Peygamber'in yeni düzenlemeyi açıklayan bir sünnetinin vârit olması halinde bahsedilebilir (bk. Zerkeşî, el-Bahrü'l-muhît, IV, 124).

79 İbn Süreyc'i nesih problemi açısından öne çıkaran bir diğer konu, kıyasla neshin cevaZ1 meselesidir. el-Vedâi'de meseleye dair açık bir ifadesine rastlanmayan İbn Süreyc'e her iki yönde görüş nispet edilmektedir (Zerkeşî, el-Bahrü'l-muhît, IV, 131-132). Hocas1 Enmâtî̀ye katılarak celî kıyasla nasların tahsis ve neshedilebileceğini savunan İbn Süreyc, kıyasın alanını genişletme yönünde bir hamlede bulunur. Enmâtî, kaynağı Kur’an olan kıyas ile Kur'an’ın, kaynağı Sünnet olan kıyas ile de Sünnet'in neshedilebileceğini savunmuştur ki bu ayırım Şâfiînnin nesih açısından Kur'an ile Sünnet'i ayrı birer küme olarak değerlendiren temel yaklaşımı ile uyumluluk arzeder. Bâcî, Enmâtîye göre celî kıyasın mefhûmü'l-hitâb olduğu ve bunun da hakiki mânada kıyas olmayıp mantuk kapsamında değerlendirilmesi gerektiğini belirtir (bk. İhkâmül-fusûl, I, 435; Zerkeşî, el-Bahrü'l-muhît, IV, 132-33). Enmâtî ve İbn Süreyc'in kıyasa nâsihlik tanıyan bu yaklaşımı Şâfiî fakihler tarafından benimsenmemiş, İbn Süreyc’in öğrencileri Sayrafî ve Ebû İshak el-Mervezî dahi buna karşı çıkmışlardır (bk. Zerkeşî, el-Bahrü'l-muhît, IV, 131-32). 
de içtihatla nesih mümkün olmayacağına göre, Şâfiînnin Sünnet ile Kur’an’ın neshine niçin karşı çıktığı anlaşılmış olur. ${ }^{80}$

V. (XI.) asırdan itibaren kaleme alınan eserlerde yer bulan ve sonraki kaynaklara da intikal eden bu tevil arayışlarına sonraki usulcüler rağbet göstermemiştir. Nitekim sonraki kaynaklarda bu tevillerin Şâfiîden yana tavır almayı haklı kılacak kadar güçlü olmadığı görülmüş ve doğrudan tenkitlere yer verilmiştir. Bu hususta Şâfiîye katılmadığını açıkça dile getiren mezhep âlimlerinden Kiyâ [İlkiyâ] el-Herrâsî (ö. 504/1110), "Büyüklerin sürçmeleri de kendileri gibi büyük olur. Bir kişinin hataları sayılabilecek kadar az ise kadri, kıymeti o denli yüce demektir" demek durumunda kalmıştır. Şâfiî̀yi takip hususundaki hassasiyetine vurgu yapılan Mưtezilî usulcü Kādî Abdülcebbâr ise (ö. 415/1025), "Şâfiî, büyük bir âlimdir ancak hakikat ondan da büyüktür" demiştir. ${ }^{81}$ Nitekim yukarıda nakledilen teviller de "Şâfiîye olan muhabbetlerinde aşırıya kaçan" mezhep âlimlerine nispet edilmektedir. Onlar, "usul ilmini vazeden" imamlarının böyle bir görüş ileri sürmesine şaşırmakla birlikte, mutlaka bir yorum getirebileceklerine inanmışlar ve imamlarına açıkça karşı çıkmaktan çekinmişlerdi. ${ }^{82}$ Sübkî, bu gibi yorumlardan ötürü işin içinden çıkılmaz hale geldiğinden yakınarak mezhep usulcülerini âdeta sağduyuya davet eder. ${ }^{83}$

\section{Mütekellimîn Usul Eserlerinde Şâfiînnin Yorumlanışı}

Şafiî̀nin çapraz neshi kabul etmeyen yaklaşımı, öğrencileri tarafından kabul görmüş, Şâfiî fikıh çevresinin intisapları zayıf ikinci nesil mensuplarınca benimsenmemiş, merkezinde İbn Süreyc'in yer aldığı ve mezhepte hâkim

8o Diğer bir tevile göre, neshe dayanarak gösterilen Bakara sûresinin 106. âyetindeki, “Biz bir âyeti neshettiğimizde" ibaresi, Kitap dışı delillerin de neshin kaynağı olabileceğine işaret etmekte ancak âyetin devamındaki, "Allah her şeye kadirdir" ibaresi, neshin kaynağının yalnızca Allah’n kudreti ile varlık bulabilen mu'ciz Kur'an olduğunu bildirmektedir. Buna göre, "Daha hayırlısını getiririz" demek, nâsihin de mensuhun da Allah'ın kudreti ile varlık bulan Kur'an olduğuna delalet etmektedir. Zerkeşî, Kiyâ [İlkiyâ] el-Herrâsînin et-Telvîh adlı eserinde bu tevilleri naklettiğini ve meseleyi Hz. Peygamber'in içtihadıyla ilişkilendiren ilk tevili uzak bulduğunu nakleder. Ona göre âyette, maslahatları bilme ve onları insanlara bildirip unutturma kudreti kastedilmektedir (bk. el-Bahrül-muhît, IV, 112-13).

81 Zerkeşî, el-Bahrü'l-muhît, IV, 112, 119.

82 Zerkeşî, el-Bahrül-muhît, IV, 112.

83 Sübkî, bu ifadelerin Şâfiî̀ye aidiyetinde bir problem yoksa inkâr edilemeyeceğini, olur olmaz tevillere başvurmanın da yersiz olduğunu söyler. Kimi Şâfiîler'in bu hususta imamlarını savunmaktan çekinmeleri, onun görüşünü zafiyete uğratacak da değildir. Nitekim Su'lûkî gibi imamın yaklaşımını sürdüren ve görüşlerini savunma gayesiyle eser yazanlar da vardır (bk. Sübkî, el-İbhâc, II, 248; Zerkeşî, el-Bahrül-muhît, IV, 113). 
fıkıh çizgisini temsil edecek olan Bağdat çevresinin mensuplarınca tevil edilmişti. Bu teviller çapraz neshi, Şâfî̀nin kaynak-yorum anlayışının esaslarını sunan beyan teorisinin sınırlarını aşmadan kabul etmenin imkânını sorgulayan arayışları yansıtır. Müteakip nesillere mensup Şâfiî usulcüler de bu arayışları anlamlı bulmuş ve mezhebin usul literatüründe ana çizgiyi bu yaklaşım temsil etmiştir. Cüveynî, Gazzâlî ve Râzî, Şâfiî̉nin nesih teorisini eleştirel bir yoruma tâbi tutan kelamcı usulcüler olarak öne çıkarlar. Mezhepte usul yazımı bakımından farklı bir tavrı yansıtan Şîrâzî ve Semânî ise bu konuda Şâfiî̀nin yaklaşımını sürdürmüş ve gerek mezhebin dışından gerekse içinden imamlarına yöneltilen tenkitlere cevap vermeye çalışmışlardır.

Mütekellimîn çizgisindeki Şâfiî usulcülerinin nesih anlayışının şekillenişinde, tevarüs ettikleri usul müktesebatının tesiri yadsınamaz. Şâfiînnin nesih anlayışını ağır ifadelerle eleştiren Cessâs ile Cüveynî-Gazzâlî çizgisinin üstadı konumundaki Bâkıllânînin çapraz nesih hakkındaki görüşleri ve geliştirdikleri argümanlar, bu yazarların eserlerinde rahatlıkla takip edilebilmektedir. Şâfiî̀nin beyan ve nesih anlayışına karşı Hanefîler'in tenkitlerini seslendiren Cessâs, el-Fusûlünde Şâfiînnin hem beyan tanımını hem de tasnifini muhtelif açlardan değerlendirmiş ve gördüğü önemli eksikliklere değinerek Şâfiî̉nin pek çok ifadesini temelden yoksun iddialar olarak görüp mahkûm etmişti. ${ }^{84}$ Cessâsin nesih-beyan ilişkisi açısından Şâfiîden farklılaştığ1 en önemli nokta, neshi bir beyan türü olarak kabul etmesidir. ${ }^{85}$ Cessâs'in eleştirisinin merkezî unsurları, Cüveynî ve Gazzâlî̉nin bu başlık boyunca nakledilecek ifadeleri ve özellikle Hz. Peygamber'in beyan vazifesini neshi de kapsayacak şekilde yorumlamalarına etki etmiş olmalıdır. Bâkıllânînin özellikle Kur'an’ın Sünnet'i neshi bağlamında Şâfî̀ye yönelttiği eleştirileri de göz önünde bulundurduğumuzda kelamcı Şâfiiler’in yaslandığı zemin daha da açık hale gelmektedir. ${ }^{86}$ Şâfiî usulünde çapraz nesih bağlamında yaşanan

84 Şâfiînnin "Beyan, kökleri itibariyle bir, ancak dalları itibariyle çeşitlenen anlamların ortak adıdır" şeklindeki beyan tanımını başarısız bulan Cessâs, bu tanımın beyanın mahiyetini tam olarak yansıtamadığını, beyanın özellikleri ve kapsamı bakımından gerekli unsurları taşımadığını söyler ve nereden alındığı belirsiz muğlak bir ifade olarak görür. Kendisi beyanı "Mânanın, içerdiği kapalılığın (iltibas) ve anlam benzerliklerinin (iştibah) giderilmesi suretiyle muhataba açık hale getirilip izah edilmesi” olarak tanımlar. Şâfiînnin yaptığı beyan taksimini de hatalı bulan Cessâs, bu taksime istenilen her şeyin dahil edilebileceğini, taksimin sınırlarının belirsiz olduğunu söyler (bk. elFusûl, I, 269-70).

85 Cessâs, geliştirdiği beyan taksiminde neshe de yer vermiş ve son sırada zikrettiği bu işlemi, "bizim vehim ve takdirimize göre bâki kalması mümkün olan hükmün müddetinin beyanı" diye tanımlamıştır (onun beşli beyan tasnifi için bk. el-Fusûl, I, 279).

86 Bâkıllânî, Şâfiî̀nin görüşünü dayanaktan yoksun zorlama bir çözüm olarak görür (bk. Zerkeşî, el-Bahrü'l-muhît, IV, 123). 
tartı̧̧malar; Şâfiînnin beyan kavramı ve nesih teorisini temellendirirken delil getirdiği âyetler etrafında yürüyen tartışmalar, onun Kư’an-Sünnet ilişkisini kurgulayışına yönelik eleștiriler ve kaynaklar arası nesihten sünnetin zarar göreceği yönündeki endişenin izalesi başlıkları üzerinden yürümektedir.

\section{a) Beyan Kavramı ve İlgili Âyetlerin Yorumuna Yönelik Eleştiriler}

Mütekellimîn geleneğine mensup usulcüler, Şâfiînnin nesih anlayışına karşı çıkarken ilk olarak onun kavramsallaştırdığı haliyle beyanı ve esas aldığı âyetler üzerinden geliştirdiği, nesihle de ilgisi bulunan yorumları tartışmaya açarlar. Bu tartışmalarla, ilgili âyetlerin kaynak-içi nesih teorisine esas teşkil etmeyeceğini göstermek isterler. Bu esnada dile getirilen eleştirilerin bir kısmı doğrudan beyan kavramına yönelik iken diğer bir kısmı ilgili âyetlerin yorumuna yöneliktir.

\section{Beyan Kavramına Yönelik Eleştiriler}

er-Risâle'de neshi beyan kavramıyla irtibatlı olarak ele alan Şâfiînnin mezhebini takip eden usulcüler, eserlerinde bu irtibatı muhafaza etmiş ancak irtibatın neshe bakışı şekillendiren yönünü değiştirmek istemişlerdir. el-Burhân'ın başında beyana ayırdığı başlıkta bu kavramı Bâkıllânîyi takip ederek delil ile özdeş kılan Cüveynî, yeni bir delil yani beyan taksimi sunmuş; aklî ve semî̀ olmak üzere ikiye ayırdığı delillerden semî̀ olanları dayanakları olan mucizeye yakınlıklarına göre sıralamıştır. Bu sıralamada sem î deliller Hz. Peygamber'den işitilen sözler, icmâ ve icmâdan telakki edilen medlullerden (haber-i vâhid ve kıyas) ibarettir. ${ }^{87}$ Cüveynî beyan/delil taksiminde Kur'an'a ve Sünnet'e aynı mertebede yer verir ve Hz. Peygamber'den telakki edilmeleri itibariyle naslar arasında ayırıma gidilmemesi gerektiğini düşünür. Cüveynî bu kabulü nesih ilişkilerini kurgularken de sürdürmüş ve kaynaklar arası neshi bu esasa dayandırmıştır. ${ }^{88}$ Buna göre, Kur'an ve Sünnet, kaynak itibariyle Hz. Peygamber'de birleştikleri için birbirlerini neshetmelerinin önünde herhangi bir engel bulunmamaktadır. Sünneti ilahî menşee dayandırma noktasında Şâfî̀̀ye katılan Cüveynî, Kur’an ile Sünnet arasında nesih bakımından bir derecelendirmeye gitmeyerek ondan ayrılmıştır. Aslında bu görüş ilk kabulün muhtemel ve beklenen sonucu iken, Şâfiî mezkûr endişelerden ötürü bu sonuca ulaşamamış ve kendi teorisini zora sokmuştu. Cüveynî, Kitabın Sünnet ile neshini ele alırken kelamcılara nispet edip kendisinin de doğru bulduğu görüş olarak bunun imkânsız görülemeyeceğini dile getirir. Hz. Peygamber kendi katından bir şey

87 Cüveynî, el-Burhân, I, 124-25.

88 Ayrıca bk. Erdem, Şâfî̀ Usûlcülerin İmam Şâfiînin Usûlünü Temsil Sorunu, s. 22. 
söylemeyeceğine, kendisine emredileni tebliğ etmiş ve farzların nasıl yerine getirileceğini açıklamış olacağına göre, beyan vazifesi kapsamında bir âyetle sabit hükmün sona erdiğini söylemesi de pekâlâ mümkündür. Cüveynî hakiki mânada nâsihin yalnızca Allah olduğunu, Sünnet'in bunu dile getirdiğini; nesih de ispat da Allah'tan olduğu için Resûlullah’n bunları tebliğ etme makamında bulunduğunu söyler. Şâfiî̉nin Kur'an ile Sünnet arasında bu açıdan yaptığı ayırımın geçersizliğini ortaya koymak üzere, neshedilen şeyin Kur’an’ın kendisi değil hükmü olduğunu belirtir. Buna göre, îcaz vasfina sahip olmayan Sünnet'in bu vasfa sahip Kur’an hükmünü kaldırmasının imkânsız olduğu söylenemez. ${ }^{89}$

Cüveynînnin Kur’an ile Sünnet arasında teşriî kuvvet bakımından tesis ettiği eşdeğerlik, kelamcı usulcülerin kabulüyle karşılaştı ve Gazzâlî, Râzî ile takipçileri konuyu bu çerçevede ele almayı sürdürdüler. Özellikle Bakara sûresinin 106. âyetinde geçen "daha hayırlı olan" ibaresi yorumlanırken dikkat çekilen bu eşdeğerlik, usulcüleri gerçek anlamda nâsihin Allah olduğu ancak neshin Hz. Peygamber'in dilinden de aktarılabileceği sonucuna götürdü. Gazzâlî, Sünnet'in Kur'an'da mevcut bir hükmün neshedildiğini bildiren bir vasıta olabileceğini belirtir. Bu yoruma göre "daha hayırlı" ile kastedilen, ilk hükümde emredilen amelden daha hayırlı bir amelin gelmesidir. $\mathrm{Bu}$ da yeni emrin ya daha kolay ve aslah olmasından ya da daha çok sevap kazandırmasından kaynaklanır. Yoksa mevcut Kur'an’n yerine daha hayırlısının gelmesi kastedilmemektedir. ${ }^{90} \mathrm{Bu}$ takdirde -Râzînin ifadesiyle- Sünnet'in içeriği pekâlâ Kur'an’ın içeriğinden daha hayırlı olabilecektir. ${ }^{91}$ Zira Sünnet de kaynağ 1 itibariyle vahye müstenittir. ${ }^{92}$

Sünnet' in esas işlevini "beyan" olarak gösteren Şâfiî, neshi bunun dışında tutmaya gayret etmiş ve Hz. Peygamber'e beyanı yükleyen âyetleri kaynak-içi nesih anlayışına delil olarak göstermişti. Tam olarak bu hassasiyet, nesih hakkında kendisine yöneltilen eleștirilerin odak noktalarından birini teşkil etmiştir. Neshi beyan olarak görenler Şâfiînnin ilgili âyetler üzerinden geliştirdiği yorumlara karşı çıkmış ve onun istidlallerini tersine çevirmeye çalışmışlardır. Mesela Râzî, Sünnet'in Kur’an’ı neshini savunur ve Şâfiî̉nin argümanlarını geçersiz kılmaya çalışırken nesih ile beyan arasında bir karşıtlık

89 Cüveynî, el-Burhân, II, 851-52; ayrıca bk. Erdem, Şâfî̀ Usûlcülerin İmam Şâfiînin Usûlünü Temsil Sorunu, s. 253-54.

9o Zira gerek kadim gerek mahluk kabul edilsin Kur'an’n bir kısmı diğerinden daha üstün sayılamaz. "Daha kolay" ifadesi Gazzâlîye, "aslah" ifadesi ise Râzîye aittir (bk. Gazzâlî, el-Müstasfâ, I, 100-101; Fahreddin er-Râzî, el-Mahsûl, I, 440).

91 Fahreddin er-Râzî, el-Mahsûl, I, 440.

92 Bu yargi, Necm sûresinin 3-4. âyetleri ile temellendirilir (bk. İsnevî, Nihâyetüs-sûul, 498; Sübkî, el-İbhâc, II, 250). 
kurmanın doğru olmadığını söyler. Şöyle ki; beyanın bir türü olan tahsis ile nesih arasında hakikatte herhangi bir fark bulunmamaktadır. Zira tahsis bir hükmü belli fertlere, nesih ise belli zamanlara özgü kılmaktan ibarettir. O halde Hz. Peygamber'in yüklendiği beyan vazifesinin unsurlarından biri de hangi âyetlerin hükmünün mensuh kılındığını insanlara bildirmektir. ${ }^{93}$ Neshi bu şekilde beyanın bir türü olarak görmek, aslında Şâfî̉nin tesis ettiği beyan teorisinden çok önemli bir noktada ayrılmak anlamına gelir. Râzînin tahsis ile nesih arasında kurduğu bu mukayeseye, sonraki usulcüler de sıklıkla atıf yaparlar. Beyanın mahiyetine dönük bu tartışmalar, nesih tariflerine de yansımış durumdadır. ${ }^{94}$ Nesih teorisinde Şâfiî̀ye muhalif Hanefî usulcülerinin yanı sıra bazı Şâfî̀ usulcülerinin de beyan kavramını tercih etmeleri dikkate değerdir. Cüveynî Hanefîler'e yakın bir tanım yaparak ${ }^{95}$ nesihte "hükmün süresinin dolduğunu bildirme" hususiyetini öne çıkarırken Gazzâlî tanımda "irtifâ" kelimesine yer vererek kaldırılma anlamını öne çıkarır. ${ }^{96}$

\section{2. İlgili Âyetlerin Yorumuna Yönelik Eleştiriler}

Şafiî̀nin nesih teorisini temellendirirken istinat ettiği dört âyet üzerinden geliştirdiği yorumlar ve bunlara cevaben ileri sürülen karşıt argümanlar, tartışmanın seyri bakımından dikkate değer unsurlar barındırmaktadır. Bunlardan ilki, "İnsanlara, kendilerine indirileni açılaman ve onların da (üzerinde) düşünmeleri için sana bu Kur'an’ı indirdik” âyetidir (en-Nahl 16/44). Bu âyet, Sünnet'in Kur'an’ beyan ettiğini bildirir ve eğer Sünnet'in Kur'an'ı neshi kabul edilirse bu beyan değil, ref' olur; Kur'an’ın Sünnet'i neshi câiz görüldüğü takdirde ise beyan ilişkisi tersine döner ve kısır döngüye götürecek bir açmazla karşılaşılır. Bu yoruma, neshin "hükmün kalktığını beyan" oluşuyla yani neshin hitapla sabit bir hükümle neyin murat edildiğini beyan ettiği -tahsisin âm lafızla ne murat edildiğini beyan ettiği gibi- argümanıyla

93 Bk. Fahreddin er-Râzî, el-Mahsûl, I, 439-40.

94 Bazı usulcüler kelamî hassasiyetlerden ötürü neshin tarifinde beyan kavramını öne ç1karırken bu endişeleri yersiz bulan daha başkaları ref' kavramını kullanırlar. Hanefîler umumiyetle beyanı benimserken Şâfiî usulcülerinin kimisi ref'i kimisi beyanı tercih etmiştir. Tanımlardaki bu fark, önceki hükmün taşıdığı devamlılık ve Allah’’n ezelî ilminde sabit hükümlerin değişmesinin mümkün olup olmadığı gibi kelamî meselelerle ilgilidir (tanımların tahlili ve karşılıklı eleştiriler için bk. İltaş, Klasik Nesih Teorisi, s. 22-35).

"اللفظ الدال على انتهاء أمد الحكم الشرعي مع التاخير عن مورده، (bk. el-Burhân, II, 842).

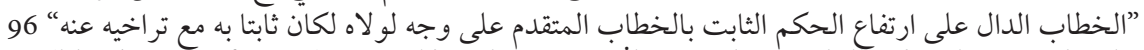
(bk. el-Müstasfâ, I, 86). Gazzâlînin bu tanımı İbn Fûrek ve Bâkıllânî̀ye dayanmaktadır (Fahreddin er-Râzî, el-Mahsûl, II, 416). İbn Berhân ve Sübkî gibi usulcüler Gazzâlînin tercihini sürdürürken; Ebû İshak el-İsferâyînî (ö. 418/1027), Ebü’t-Tayyib et-Taberî (ö. 450/1058), Râzî ve Beyzâvî Cüveynî ile aynı tanımı benimsemiştir. 
cevap verilmiştir. Kısır döngü iddiasına ise Kur'an’ın, "Her şeyin açıklayıcısı" (en-Nahl 16/89) olmasıyla cevap verilmiştir.97

Şâfiînnin istinat ettiği ikinci âyet, "Biz bir âyeti değiştirip yerine başka bir âyet getirdiğimiz zaman -ki Allah neyi indireceğini gayet iyi bilir- onlar Peygamber'e, 'Sen ancak uyduruyorsun' derler” âyetidir (en-Nahl 16/101). Ona göre bu cümle, bir âyetle sabit hükmün yine bir başka âyetle neshedilebileceğini bildirir. Bu yoruma, âyetle sabit bir hükmün âyet dışında başka bir şeyle neshedilmeyeceği mânasının bu âyetten çıkarılamayacağı argümanı ile cevap verilmiştir. ${ }^{98}$ İstinat edilen bir diğer delil, "Âyetlerimiz kendilerine apaçık birer delil olarak okunduğunda, (öldükten sonra) bize kavuşmayı ummayanlar, 'Ya (bize) bundan başka bir Kur'an getir veya onu değiştir' dediler. De ki: Onu kendiliğimden değiştirmem benim için olacak şey değildir. Ben ancak bana vahyolunana uyarım” âyetidir (Yûnus 10/15). Şâfiî, Sünnet'in Kur'an'ı neshini kabul etmenin Hz. Peygamber'in âyet hükümlerini kendiliğinden değiştirmesi anlamına geleceğini söyleyerek karşıt görüşe itiraz eder. Bu yoruma, Hz. Peygamber'in Kur'an'ı sadece kendisine vahyedilene tâbi olarak neshedeceği argümanı ile cevap verilmiştir. Bu durumda müşriklerin, "Bunun dışında başka bir Kur’an getir veya onu değiştir” sözü, Kur’an’ın hükümlerinin değil lafızlarının değiştirilmesi anlamına gelecektir. ${ }^{99}$ Şâfiî son olarak "Biz herhangi bir âyeti nesheder veya onu unutturursak yerine daha hayırlısını veya mislini getiririz" (el-Bakara 2/106) âyetini birkaç açıdan yorumlayarak görüşünün dayanağı haline getirir. Bu yorumlar, Kur'an’ın ancak kendi cinsinden bir delille değiştirileceği, âyetteki “biz" ifadesinin Allah'a yani Kur'an'a delalet ettiği ve Sünnet'in Kur'an'dan daha hayırlı olduğunun söylenemeyeceği argümanlarına yaslanmaktadır. ${ }^{100}$

$97 \mathrm{Bu}$ âyete göre, Kitabın Sünnet'i de beyan ettiğini kabul etmek gerekir ancak bu durumda diğer âyetle teâruz edeceği için delil olarak kullanılamaz hale gelir (İsnevî, Nihâyetü's-sûl, s. 499; Sübkî, el-İbhâc, II, 250). Karâfî̀ kısır döngü iddiasına cevap verirken Kur’an ve Sünnet arasında karşılıklı bir beyan ilişkisi kurar ve her iki kaynağın bütünüyle kapalı olmadıkları gibi bütünüyle açık da olmadıklarını ve her birinin diğerindeki kapalılıkları açıklığa kavuşturduğunu söyler (bk. Şerhu Tenkïhil-fusûl, s. 245).

98 Ayrıca bu âyet, âyetlerin hükmünün değil, nassının değiștirilmesini belirtir. Diğer taraftan Hz. Peygamber, Kur'an’ı ancak kendisine bir vahiy geldiği zaman nesheder, bunu getiren de Cebrâil'dir (bk. Ebü'l-Hüseyin el-Basrî, el-Mu'temed, I, 394-95).

$99 \mathrm{Bu}$ âyet, karşıt görüşün delili olarak da ileri sürülmüştür. Şöyle ki; âyete göre Hz. Peygamber neshedenin kendisi olmadığını, vahye tâbi olduğunu beyan etmiş olmaktadır (bk. Cüveynî, et-Telhîs, II, 519).

100 Âyetlerin yorumu etrafında seyreden tartışmalar için bk. Ebü'l-Hüseyin el-Basrî, elMu'temed, I, 395-97; Cüveynî, et-Telhîs, II, 520; Fahreddin er-Râzî, el-Mahsûl, II, 439441; İsnevî, Nihâyetü̉s-sûl, s. 498-99; Sübkî, el-İbhâc, II, 273-74. 


\section{b) Kur’an-Sünnet İlişsisinin Kurgulanışına Yönelik Eleştiriler}

Şâfiî̀nin kaynak-içi nesih teorisini benimsemeyen usulcüler, en yoğun ve ağır eleştirilerini neshin işleyiş süreciyle ilgili açıklamalarına yönelttiler. Şâfiî, kaynaklar arasındaki ilişkinin tesisinde oldukça ihtiyatlı davranmış; Kur'an’n Sünnet'i neshettiği kabul edildiği takdirde bir şekilde Kur'an’a aykırı görülebilecek bütün rivayetlerin reddedilebileceğinden ve nesih bir yana tahsis ve takyit gibi işlemlerin dahi itirazla karşılaşacağından korkmuştur. İște kelamcı Şâfiî usulcüleri tam bu noktada imamlarından ayrılırlar. Cüveynî, delil/beyan anlayışı gereğince Kur'an ile Sünnet'in mahiyetleri bakımından değil, bize intikal ediş keyfiyetleri yani rivayetteki katîlik-zannîlikten hareketle ayrılması gerektiğini düşünür. ${ }^{101}$ Buna göre sübut bakımından kat'iyyet arzeden Kur'an ile mütevatir hadisler bir tarafta, zanniyyet arzeden âhâd hadisler ise diğer tarafta yer almalıdır. ${ }^{102}$ Cüveynî, nesih konusunda Sünnet ile Kur'an’ı o kadar aynîleștirir ki neshin ispatı için geliştirilmiş bütün delillerin aynı zamanda Sünnet'in Kur'an’ı neshine dayanak teşkil ettiğini söyler. Cüveynî, meseleyi metlûv - gayri metlûv vahiy bağlamına taşıyarak Kur'an ve Sünnet'in kaynak bakımından aynı olduğunu, aralarındaki tek farkın -hücciyet bağlamında- bize intikal ediş şekillerinde tezahür ettiğini belirtir. ${ }^{103}$

Konuyu aklî ve şerî̀ imkân açısından bir soruşturma yaparak ele alan Cüveynî, sünnetin hilafına Kur'an âyeti inmesinin imkânsız olmadığını savunur ve buna karşı çımanın tarihen sabit bir durumu inkâr etmek anlamına geldiğini söyler. Bunun mümkün olduğu kabul edildiği halde yine Şâfiî̀nin tezine dönülür ve "Bu durumda Peygamber önceki sünneti nesheden yeni bir sünnet koyar" gibi "zorlama" izahlara başvurulursa, "hakikatlerle oynanmış ve alay edilmiş” olur. ${ }^{104}$ Kur'an’ın nâsih hükmü ile nesih gerçekleşmiş olduğuna göre bunun öğrenilmesi ne diye bir başka kaynağa yani sünnet ile sabit olacak yeni bir hükme bağlanmış olsun? Gazzâlî de bu hususta Şâfiînnin görüşünü savunulamaz bulur ve iki kaynak arasında hiçbir şekilde neshin olmadığını söylemenin tahakküm yani delile dayanmayan keyfî bir yargı olduğunu belirtir. ${ }^{105} \mathrm{Bu}$ noktada Cüveynî, belki de Şâfî̀yi bu ağır ithamların

101 Cüveynînin bu yaklaşımı ile Cessâs’n yaklaşımı ve Şâfiî̀ye beyan üzerinden yönelttiği tenkitler arasında ciddi bir paralellik bulunmaktadır.

102 Bk. Cüveynî, el-Burhân, II, 854 .

103 Aynı husus, Hz. Peygamber’in içtihat ettiği kabul edildiği takdirde de geçerliliğini korur (bk. Cüveynî, et-Telhîs, II, 516).

104 Bk. Cüveynî, el-Burhân, II, 852; benzer açıklamalar için bk. Gazzâlî, el-Menhûl, s. 388-90.

105 Gazzâlî, Şâfiî̉nin bu ifadeleriyle neshin çoğunlukla bu şekilde gerçekleştiğini vurgulamak istemiş olabileceğine ve bu takdirde tartışmaya değer bir husus olmadığına da işaret eder (bk. el-Müstasfâ, s. 10o; değerlendirmesi için bk. Erdem, Şâfî̀ Usûlcülerin İmam Şâfiînin Usûlünü Temsil Sorunu, s. 147). 
muhatabı kılmama gayretiyle, Ebû İshak el-Mervezînin işaret ettiği yoruma istinaden Şâfiînnin Kur'an’n Sünnet'i neshine dair net bir görüşü olmadığ neticesine ulaşır. Diğer taraftan, Sünnet'in Kur'an’’ neshine kesin bir biçimde karşı çıkan Şâfiînnin Kur’an’’n Sünnet'i neshine dair kesin bir kanaati olmadığını göstermeye çalışır. Cüveynîye göre burada kesin olarak doğruluğu savunulabilecek görüş, kelamcıların da benimsediği üzere, Kitabın sünnet ile neshini imkânsız görmemektir. ${ }^{106}$ Gerçekte nâsih olan yalnızca Allah'tır, bu sıfatın peygamber hakkında kullanılışı mecaz kabilindendir. ${ }^{107}$ Ayrıca Sünnet Kur’an’’n kendisini değil, hükmünü neshettiği ve Kur'an’ın îcaz yönü sadece hükmünde değil, bütününde yani nazmında olduğu için ícaz üzerinden yöneltilen itirazlar da yersizdir. ${ }^{108}$

Gazzâlî, Cüveynînnin tartıştığı ve ulaştığı kanaati müsellem sayarak kaynakların birbirini neshini kabul eder. Kaynaklar arasında cins farklılığına itibar edilemeyeceğinden ve birbirlerini neshetmelerinin aklen imkânsız olmayışından hareketle, çapraz neshi kabulün önünde herhangi bir mani bulunmadığını düşünür. Hatta birçok örnekte görüldüğü üzere Kur’an Sünnet'teki hükmü, Sünnet de Kur'an'daki hükmü neshetmiştir, bunlar vâki ve malumdur der. ${ }^{109}$ Cüveynînin açıklama ve argümanlarını benzer cümlelerle dile getiren Gazzâlî, Kur’an ile Sünnet arasındaki farklılığın özde değil ibarelerde olduğunu söyler ve bu ibarelerin hepsi Resûlullah'tan işitildiğine göre aralarında bir ayırıma gidilemeyeceğini savunur. ${ }^{110}$ Yine, sünnetle sabit bir hükmün Kitap ile neshedilirken yeni bir sünnet geldiğini ve hakiki nâsihin bu olduğunu savunmayı anlamsız bir izah çabası olarak görür. Bu noktada Şâfiî̀yi doğrudan tenkit etmeme adına onun sözlerini yorumlamaya çalışır. ${ }^{111}$

106 Cüveynî, Ebü’l-Hüseyin el-Basrîde de görüldügü üzere, Sünnet'e Kur'an üzerinde bu kabilden bir belirleyicilik tanınması noktasında, Hz. Peygamber'in yalnızca kendisine vahyedileni ilettiği kabulünden hareket eder. Hz. Peygamber bir tebliğci olarak pekâlâ ümmetine bir âyetin hükmünün kaldırıldığını da iletebilir (bk. Cüveynî, el-Burhân, II, 851).

107 Cüveynî, et-Telhîs, II, 461.

108 Cüveynî, aksi görüşün dayanağ1 sayılan âyetin (el-Bakara 2/106) ihbârî nitelikli olduğunu, başka türlü nesihleri yani Kur'an’ın Sünnet ile neshini imkânsız kılmadığını belirtir (el-Burhân, II, 852). Nitekim karşıt görüşü savunanlar da Hz. Peygamber'in bir âyetin lafzını ibka ettiği halde hükmünü neshetmiş olabileceğini kabul ederler. Onlar, Hz. Peygamber Kur'an’’n tilavetini değiştirebilir ancak hükmünü değiştirmiş olamaz diyerek cevap veremezler zira tilavet de Kur'an’ın hükmüne dahildir (bk. Cüveynî, et-Telhîs, II, 518).

109 Gazzâlî, el-Müstasfâ, I, 99-100.

110 Gazzâlî, el-Müstasfâ, I, 100.

111 Gazzâlînin izahına göre Şâfiî̀ kaynaklar arası neshi imkânsız görürken $\mathrm{Hz}$. Peygamber'in bir âyet gelip de hükmünü neshedene kadar kendi hadisi ile sabit bulunan önceki hükmünü değiştirmediğini kastetmiş olabilir (bk. el-Menhûl, s. 391). 
Cüveynî ve Gazzâlînnin bu yaklaşımlarının yukarıda işaret edildiği üzere Basrî ve Bâkıllânîye dayandığını söylemek mümkündür. ${ }^{112}$

\section{c) Çapraz Nesihten Sünnet'in Zarar Göreceği Yönündeki Endişenin İzâlesi}

Çapraz neshe karşı çıanlar, Kur'an’ın Sünnet'i neshi kabulünün Sünnet deliline zarar vereceği ve Sünnet' in Kur'an’ı neshinin de Kur'an’ın mevsukiyetine gölge düşüreceğinden endişe duyarlar. İkinci endişeyi dile getirenler, bu kabulün "Hz. Peygamber Kur'an’ı kendiliğinden değiştirmiş olabilir" iddias1na zemin teşkil edebileceği yönünde bir uyarıda bulunurlar. Bununla irtibatlı bir diğer aklî gerekçe, "Sünnet Kur'an’ı nesheder" demenin Hz. Peygamber' in mucizesini kaldırmak anlamına geldiğidir. Onlar, Hz. Peygamber’in sıdk1nı gösteren bir delilin O’ndan bu şekilde çekip alınamayacağını savunurlar. ${ }^{13}$ Cüveynî karşıt görüşün aklî gerekçelerini çürütürken Hz. Peygamber hakkında böyle bir düşünceye kapılmanın yanlışlığına vurgu yapar. Hz. Peygamber'i bu tür şüphelerden korumaya gerek dahi olmadığını söyleyen Cüveynî, O’na imanı fiilî durumun ve aksi yöndeki bütün ihtimallerin önüne geçen bir unsura dönüştürür. ${ }^{114}$

İlk endişeden hareketle çapraz neshe karşı çıkan Şâfiî ve takipçileri, Sünnet'in ve özellikle de âhâd hadislerin mevcut teâruzlar ileri sürülerek devre dışı bırakılacağından korkarlar. Ne var ki kelamcı usulcüler Kur’an ile konmuş yeni hükmün bilgisinin yine sünnetten elde edildiğini tarihî bir gerçeklik sayarak sünnetin Kur’an tarafından neshinde bir mahzur görmezler. Nihaî hükmün Hz. Peygamber'in uygulamasıyla bilineceği kabul edildiği takdirde Şâfiînnin itirazı anlamını da yitirmiş ve onlar nazarında, "Nâsih olan Sünnet'tir" cümlesi yerine "Nâsih olan Kur'an'dır" denmesinde bir sakınca kalmamıştı. Cüveynî ve Gazzâlînnin Şâfiî̀nin endişesine doğrudan temas eden herhangi bir açıklamaya başvurduğunu görmüyoruz ancak onların Şâfiî sonrasındaki gelişmeleri göz önünde bulundurarak II. (VIII.) asırdaki tartışmaların yol açtı̆̆ 1 endişelere artık mahal kalmadığını düşündüklerini söyleyebiliriz. Şâfî̉nin de etkin bir şekilde içinde yer aldığı bir etkileşim ve telif ameliyesi akabinde farklı fikıh çevreleri görüşlerini ve dayanaklarını açıkça dile getirmişler ve böylece Şâfiînnin Sünnet delili etrafındaki kimi

112 Gazzâlî, kaynaklar arası nesih ilişkisini temellendirirken Şafiî̀nin izahını dayanaktan yoksun gören Bâkıllânînin çizdiği hatta yürür; onunla benzer gerekçeler ileri sürer ancak bu delillerin tartışılabilir olduğunu ifade etmekten de geri durmaz (elMüstasfâ, I, 100). Deliller etrafında yürüyen tartışmalar için bk. Gazzâlî, el-Menhûl, s. 387-91.

113 Ebüll-Hüseyin el-Basrî, el-Mu'temed, II, 516.

114 Cüveynî, et-Telhîs, II, 517. 
endişelerinin yersiz olduğu ortaya çıkmıştır. Hanefîler'in umumun katîliği üzerinden inşa ettikleri nas yorum teorisi birçok konuda Şâfiîler'in itirazına sebebiyet vermişse de çapraz neshi bu bağlama yerleştirerek karşı çıkmaya gerek olmadığı bizzat bu mezhebin usulcüleri tarafından da teslim edilmiş olmalı ki aynı endişelere ilerleyen dönemlerde neredeyse hiç değinilmeyecektir. ${ }^{115}$ Şu da var ki mezhepte çapraz neshin kabulü hâkim görüş haline geldikten sonra da tartışmalar devam etti. Özellikle verilen örneklerin uygunluğu üzerinden yürüyen tartışmalar, konunun her daim yeniden ele alınmasına ve herkesçe kabul gören nihaî bir uzlaşıya varılamamasına yol açtı. Bir sonraki başıkta, Şâfiînnin çapraz nesih anlayışını sürdürme yanlısı olan iki usulcünün yaklaşımı aktarılarak mezhep içerisinde yürüyen tartışmaların diğer bir veçhesine ışık tutulacaktır.

\section{d) Şîrâzî ve Semââìnin Yaklaşımı}

V. (XI.) asırdan itibaren Şâfiî usul yazımına hâkim olan kelamcı âlimlerin çapraz neshe yaklaşımı, müteakip dönemlerde kaleme alınan eserlerde sürdürülmüş ve konu bu usulcülerin çizdiği çerçevede işlenmiştir. Bu çizgiyi takip eden usulcüler imamlarını büyük ölçüde yalnız bırakırken kelama daha mesafeli olan ve Şâfiilik içerisinde ehl-i hadis kanadına yakın görülebilecek diğer bazı usulcüler daha farklı bir tavır ortaya koymuştur. Eşârî kelamını benimsemeyen Şîrâzî ve Semânî, nesih meselesinde Şâfiî̀nin yaklaşımını sürdürmeye gayret etseler de onunla bütünüyle hemfikir olduklarını söylemek güçtür. Ulaştıkları neticeleri imamlarına nispet etmeye çalışan bu iki usulcü, imamlarına diğerleri gibi açıktan karşı çıkmayı uygun görmemişlerdir. Onların ulaştığ 1 ilk sonuç, Şâfiî̉nin "aklen câiz olmakla birlikte sem' açısından câiz değil” anlamına gelmek üzere çapraz neshe karşı çıktığıdır. ${ }^{116}$ Aklî imkânın tesisinde hemfikir olan bu iki âlimden Şîrâzî̀, Kur'an’ın Sünnet'i neshi hususunda Şâfiî̀ye nispet edilen iki görüşten cevaz yönündekini sahih bulurken Semânî aksi görüşü sahih bulur. ${ }^{117}$

Şirâzî, kaynakları üstünlük sıralamasına tâbi tutarak "Kitabın Kitabı neshi câiz olduğuna göre, Sünnet'in kendisinden üstün olan Kitap ile neshi evleviyetle câizdir" der. Ona göre, Sünnet'in Kitap ile tahsisi câiz olduğuna göre, neshinin de câiz olması gerekir. Ayrıca Şîrâzî Şâfiînnin beyan üzerinden tesis

115 Mesela İbn Fûrek, Şâfîiler’in çoğunun Kur'an’ın mütevâtir sünnet ile neshini kabul ettiği ve Eş'arînnin de bu görüşte olduğunu aktarır (bk. İbn Fûrek, Mücerredü makālât, s. 199-201). Zerkeşî, Eş̧arîler ile Mưtezile ve diğer kelamciların da bu görüşü benimsediğini belirtir (bk. el-Bahrüll-muhitt, V, 262).

116 Şîrâzî, Şerhu’l-Lüma', I, 501; Semânî, Kavâtıu'l-edille, I, 450; ayrıca bk. Zerkeşî, elBahrü'l-muhit, V, 268.

117 Şîrâzî, Şerhu'l-Lüma', I, 499; Semânî, Kavâtıu'l-edille, I, 456. 
ettiği ilişkiyi de tersine çevirerek ondan önemli bir konuda ayrılır. Buna göre şâri', Sünnet'i Kur'an’ın beyanı kılarken Kur'an’ın Sünnet için evleviyetle beyan olduğu hususunda da bir "tembih"te bulunmuş olmaktadır. Zira Kur'an Sünnet'ten daha üstündür, daha alt mertebedekinin daha üstün olanı beyanı câiz ise aksi evleviyetle câiz olmalıdır. Bu kabul, Şâfiînnin duyduğu endişenin bütünüyle göz ardı edildiği anlamına gelir. ${ }^{118}$ Şîâazî, Kur'an’n Sünnet'i neshini kabul ederken Sünnet' in Kur'an’ı neshine karşı çıkarak Şâfiîyi takip etse de Şâfiînnin kaynaklar arası neshe karşı çıkarken dayandığı en önemli gerekçeyi benimsemez. Ona göre Kur’an’’n Sünnet ile neshinin mümkün olmaması, bu ikisinin farklı cinsten olmasından değil, birinin asıl diğerininse onun fer'i konumunda olmasından ileri gelir. Kur’an Sünnet’ten üstün olduğu için aslın kendi fer'i ile yani üstün olanın kendisinden aşağı olanla neshi kabul edilemez ancak aksi kabul edilebilir. ${ }^{119}$

Şîrâzî, nesih teorisinin Şafiî̀ye destek olduğu kısmında onun görüşünü yeni argümanlar geliştirmek ve sonraki kavramsal çerçeveyi bu tartışmaya eklemlemek suretiyle güçlendirmek istemiştir. Sünnet'in Kur'an’ı niçin neshedemeyeceğini temellendirirken kadim-muhdes ayırımını devreye sokması bu bağlamda önemlidir. Şîrâzî, Allah’n kadim yani ezelî kelamı olan Kur'an’ı muhdes yani sonradan varlık bulmuş Sünnet' in ortadan kaldırmasının mümkün olmadığını savunur. Buna karşı çıkılamayacağı için aksi görüşü desteklemek üzere geliştirilmiş bütün argümanlar kendiliğinden geçersiz hale gelecektir. ${ }^{120}$ Şîrâzî, tahsisten hareket edilerek geliştirilen, "Sünnet nasıl Kur’an’ı tahsis edebiliyorsa neshetmesi de mümkündür" argümanına da itiraz eder ve niçin geçersiz olduğunu göstermek için karşıt argümanlar üretir. ${ }^{121}$

118 Şîrâzî, Şerhu’l-Lüma', I, 50o. Şîrâzînin nesihle tahsis arasında kurduğu ilişkinin eleştirisi için bk. Beroje, "İmam Şafiînnin Nesh Anlayışı”, s. 64. Şîrâzî, bu noktada daha da ileri giderek Şâfiî̀nin beyana yüklediği temel fonksiyona dahi karşı çıar ve mütekellimîn usulcüleri gibi beyanın izhar ve tebliğ olduğunu savunur (bk. Şîrâzî, Şerhu'l-Lüma', I, 499-500).

119 Şîrâzî bu istidlali, mütevâtir hadisle âhâd hadis arasındaki ilişkiye de taşır, bir kıyasla başka bir kıyas hükmünün de neshedilemeyeğine işaret ederek cins birliği argümanını bütünüyle geçersiz kılmak ister (Şerhu'l-Lüma' I, 500-501). Şîrâzînin cins birliği argümanına karşı geliştirdiği eleştirinin Şâfî̉nnin görüşleri ile ilgisinin zayıflı̆̆ hakkında bk. Beroje, “İmam Şafiî̀nin Nesh Anlayışı”, s. 65.

120 Aksi takdirde aslın kendi fer'i ve daha düşük konumdaki bir şey ile ortadan kaldırılması söz konusu olacaktır ki bu kabul edilemez (bk. Şîrâzî, Şerhu'l-Lüma', I, 506).

121 Şîrâzî, bu tarz bir kıyastan hareketle neshin temellendirilmesini üç açıdan geçersiz bulur: a) Kıyasla tahsis câiz olduğu halde, kıyasla neshin câiz olmayacağı üzerinde icmâ vardır. b) Lafzın içeriğinin bir kısmının beyan yoluyla iskatı mânasındaki tahsis, Sünnet ile yapılabilir ancak nesih böyle değildir, çünkü nesih lafzın bir kısmının değil tamamının iskatıdır. Bu açıdan, kendisinden aşağıda olan bir delille nesih câiz değildir. c) Tahsis, deliller arasında cem` ve tertibi tazammun etmesi hasebiyle haber-i 
Semânî konuya, Şâfiînnin bütün eserlerinde Kur'an’n Sünnet ile neshine karşı çıktığını ancak bunun gerekçesinin ne olduğuna yönelik tartışmalar esnasında farklı görüşlerin dile getirildiğini belirterek başlar. Onun çıkarımına göre, Şâfiî nazarında çapraz nesih hem aklen hem de şeran imkânsızdır. ${ }^{122}$ Semânî, muhaliflerin getirdiği delilleri geçersiz kılmaya çalışırken, Sünnet'in Kur'an'ı neshi kabul edildiği takdirde, Kur'an’’n mutlak mânada üstünlügünün (hayr) halel göreceğini savunur. ${ }^{123}$ Cüveynînin dile getirdiği üzere hakikatte nâsihin Allah, bunu dile getirenin Hz. Peygamber olduğu şeklindeki düşünceye de karşı çıkar. $\mathrm{Bu}$ türden bir nesih netice itibariyle $\mathrm{Hz}$. Peygamber'e nispet edildiği ve de vahyin muhtelif türleri olduğu için bu argümanı isabetsiz bulur. Yine bu ve ilgili başka âyetler üzerinden ileri sürülen diğer gerekçeler ve Şâfiî̀ye yöneltilen itirazlara da benzer düşüncelerle cevap verir. ${ }^{124}$ Semânî kendi konumunu haklı çıkarmak için bütün gayretini sarfetmekle birlikte, meselenin oldukça müşkil olduğunu söylemekten de geri durmaz. Kendisi gibi Kur'an’ın Sünnet tarafından neshini kabul etmeyenlerin görüşlerini aklî argümanlarla temellendirmelerini uygun bulmayan Semânî, bu noktada dile getirilecek en ileri gerekçenin Kur’an’n Sünnet'ten üstünlügü olduğunu, bununsa kolaylıkla geçersiz k1lınabileceğini belirtir. Ona göre meseleyi aklî cevaz üzerinden değil, şer î deliller muvacehesinde tartışmak gerekir. Bu türden delillerin kendisini desteklediğini düşünen Semânî, aksini savunanlar tarafından ileri sürülen örneklerin hepsini bir şekilde izah eder ve şer'de bu tarz bir neshin hiç vâki olmadığını ispatlamaya çalışır. ${ }^{125}$

Semânî, Kur’an’in Sünnet'i neshi hususunda, Şâfiînnin er-Risâle’nin kadim ve cedit versiyonlarında açıkça karşı çıkmasına rağmen ashabının ona iki farklı görüş nispet ettiklerini söyler. Karşı çıktığı şeklindeki görüş onun genel ifadelerine daha uygun olsa da kabul yönündeki görüşün doğru bulunmaya

vâhid ile gerçekleşebilir ancak nesih iki delilden birinin diğeri tarafından iskat edilmesi olduğu için üstün olanın ednâ olanla neshi câiz değildir (Şerhu'l-Lüma', I, 507). Beroje bu tartışmayı mutlak olarak Sünnet'in Kur'an’ı neshi bağlamında aktarırken Şîrâzî̀nin söz konusu argümanları, "âhâd haberle Kitabın neshi”ni kabul edenlere kar§̧ı zikretmiş olduğuna dikkat etmek gerekir (bk. “İmam Şafiînnin Nesh Anlayışı”, s. 76).

122 Semânînnin bir diğer tespiti, şer’an men'i savunanların da kendi içlerinde farklı görüşlere ayrıldıklarıdır. İbn Süreyc, şer'an imkânsızlığı bu tarz bir neshin vuku bulmamasıyla temellendirirken Ebû Hâmid el-İsferâyînî, şer'in bunu açıkça menettiğini ileri sürmüştür. Semânî bu konuda İbn Süreyc’i destekler (bk. Kavâtıu’l-edille, I, 449-50).

123 Semânî, Kavâttu'l-edille, I, 453.

124 Semânî, Kavâtıu'l-edille, I, 453-54.

125 Mesela zina eden kadınların ev hapsine tâbi tutulmaları sonrasında inen recm âyeti hakkında şunları söyler: Ezayı, ev hapsini ve celdeyi emreden âyetler bekârlar hakkında inmiştir, recm cezası ise muhsanlar hakkında sünnet tarafından ilkten konulmuş bir hükümdür (bk. Semânî, Kavâtıu'l-edille, I, 454-55). 
daha çok elverişli olduğunu belirtir. ${ }^{126}$ Semânî, Kur'an’ın Sünnet'i neshini kabul etmenin iki kaynak arasındaki beyan ilişkisini tersyüz edeceği gerekçesini anlamsız bulur. İlgili âyetten hareketle, bu nesih türüne karşı çıkmanın Hz. Peygamber'den bu tarz bir beyan dışında hiçbir sözün sâdır olmayacağ anlamına geleceğini belirtir. Neshin aynı cinsten kaynaklar arasında yürütülmesi gerektiği yönündeki gerekçeyi de zayıf bulan Sem‘ânî, pek çok defa vâki oluşunu bu nesih türünün en önemli delili sayar. ${ }^{127}$

\section{Değerlendirme ve Sonuç}

Kaynaklar arası nesih meselesi, fıkıh usulü ilminin konusunu teşkil eden meselelerin nasıl ele alınıp tartışıldığı, problemlerin tarihsel bağlamlara göre hangi anlamları kazanıp kaybettiği ve serdedilen görüşlerin kıymet kazanması ve kıymetten düşmesinde usulcülerin içinde bulunduğu özel ve genel bağlamların hangi düzeylerde tesirde bulunduğunu takip etmek için önemli bir örneklik teşkil eder. Fıkıh ilminin ilk tedvin sürecini tamamladığı ve Kitap, Sünnet ve içtihatla ilgili yoğun tartışmaların şekillendirdiği tarihsel bir bağlamda nesih anlayışı şekillenen Şâfiî, taşıdığı kimi endişeler ve fıkha yön verebilme adına dile getirdiği fikirler doğrultusunda geliştirdiği kaynak telakkisinin bir unsuru olarak çapraz neshe karşı çıktı. Şâfiînnin hâkim fikıh çevrelerine karşı geliştirdiği eleştirel söylem ve bu arada inşa etmeye çalıştığ1 yeni fikıh telakkisi, yalnızca teorik bir tartışmadan ibaret kalmadı ve fürû-i fıkıhtaki tekliflerinin de karşılık bulmasıyla yeni bir mezhebin vücut bulmasına imkân tanıdı. Nesih konusu bu eleştirel söylem içerisinde onun en hassas olduğu noktalardan birine karşılık geldiği ve dönemi itibariyle ileri, belki de uçlarda addedilebilecek bir yaklaşım olduğu için çok dikkat çekmiş, bir dönem tevil edildikten sonra önce kısmen sonra da en azından mezhebin bazı âlimlerince bütünüyle terkedilmiştir.

Çapraz neshin Şâfiî fikıh geleneğindeki seyri, bir bütün olarak fakihler arasında daha büyük uzlaşılar elde edildiği takdirde bazı meselelerde geçmişte benimsenen tavrın zamanla destekten yoksun hale gelebildiğini gösteren önemli bir örnektir. Mezhep âlimlerinin vaktiyle sahiplendikleri bir görüş, bizzat mezhep imamı tarafından dillendirilmiş ve ısrarla savunulmuş olsa dahi, fukahanın daha çok önemsediği büyük uzlaşılar gereği terkedilebilmiştir. Şâfiînnin çapraz neshe karşı çıkarken inşa etmeye çalıştığg Kur'an ve Sünnet tasavvurunun kendisinden sonraki yıllar boyunca ciddi bir karşılık bulması yani farklı mezheplere mensup fakihlerin bu kaynakları birbirini

126 Semânî, Kavâtıu'l-edille, I, 456.

127 Cins birliği argümanına yönelttiği itiraz, Şâfiî̉nin ifadeleri hatırlandı̆̆ında hassaten önem kazanır (bk. Semânî, Kavâtıu'l-edille, I, 456-57). 
kırıp ögüten değil, bilakis açıklayıp tamamlayan aynı bütünün parçaları olarak görmeleri, onun zorlama olarak görülmeye başlanan ve elde edilen uzlaş1 itibariyle artık bir değeri kalmayan yaklaşımını sürdürmeye gerek bırakmadi. Bu noktada özellikle mütekellimîn çizgisindeki usulcüler, Şâfiînnin öncüllerinin muhtemel sonuçlarını dillendirmek ve onun birtakım istidlallerini de tersine çevirmek suretiyle çapraz neshe mezhep bünyesinde yer açtılar. Bu çizgiye mesafeli mezhep âlimleri dahi bu genel temayülün etkisine girerek çapraz neshi bütünüyle olmasa da bir yönüyle benimsediler ve Kur'an’’n Sünnet'i neshini kabul ettiler.

Şâfiî usul eserlerinde ilgili tartışmaların takibi, fikıh usulünün mahiyetine ve klasik dönemlerde algılanı̧ biçimine dair bazı sonuçlara ulaşmaya imkân tanır. Bu disiplin, hususan mütekellimîn geleneğinde yalnızca mezhep düzleminde açıklamalar getirmeyi hedefleyen bir uğraşı alanından ibaret görülmediği için mezhebi aşan ve bütün fakihlerce temsil edilen dinîşerî̀ düzlemde açıklamalar geliştirebilme çabalarını yansıtır. Şöyle ki; fıkıh usulünün başlıca gayelerinden biri ahkâm-1 şer iyyenin nasıl vücut bulduğunu, bu hükümlerin hangi kaynaktan nasıl sâdır olduğunu ve her bir hükme mesnet teşkil eden delillerin aralarındaki ilişki biçimlerini beyan etmek olarak görülecek olursa, belli bir tarihte geliştirilmiş bir açıklama modelinin sonraki yıllarda kimi açlardan başarısız bulunması halinde tadil ve tashihlere konu olması kaçınılmaz hale gelmiş ve bunu yapmayı üstlenen usulcüler bizzat imamlarına rağmen gerekli müdahalelerde bulunmaktan geri durmamışlardır. Şâfiî usulcüleri, imamlarının geliştirdiği kaynak ve yorum anlayışının esaslarından biri olan beyan teorisinin gereği olarak benimsediği çapraz nesih aleyhindeki tavrın artık izah gücünü kaybettiğini görmüş ve Kur'an-Sünnet ilişkilerini bu açıdan yeni bir zemine yerleştirme ihtiyacı duymuşlar; böylelikle usulün dar anlamda mezhebî değil, dinî-şerî̀ açıklayıcılığının gereğini yerine getirerek yeni bir modele ulaşmışlardır. Bu yeni açıllama modeli, mezhebe mensup âlimlerin III (IX) ve IV. (X.) yüzyıllar boyunca yürüttükleri tartışmalar sayesinde gelişip şekillenmiştir. İlkin aklî imkân-şer î imkân ayırımı etrafında seyreden tartışmalar, bir süre Şâfiînnin gerçekte neyi savunduğunu tespite yönelmiş, hem imamın teorisini üzerine inşa ettiği temel kabuller zedelenmeden hem de ahkâmın teşrî sürecini aktaran rivayetlerle daha uyumlu görünecek bir nesih anlayışı geliştirmenin peşine düşülmüştür.

Şâfiî̀nin fikıh usulü edebiyatının mütekâmil ilk metinlerinden itibaren çapraz nesih konusunda tenkide tâbi tutuluşu, mezhep âlimlerini etkilemiş görünmektedir. Cessâs’’n Kur'an-Sünnet ilişkisini tesis ederken kaynakların mahiyetlerine göre yapılan ayırımdan değil, sübutları ve ifade ettikleri 
bilginin derecesinden hareket edişi, çapraz neshin kabulünü kolaylaştıran en önemli hamledir. Neshin beyanla ilişkisinin farklı bir tarzda kurgulanışı ve bu işlemin nihayetinde beyan kapsamında görülüşü yine Şâfiînnin kaynak telakkisine yöneltilmiş önemli bir eleştiridir. Diğer taraftan Bâkıllânî çizgisinde şekillenen Cüveynî-Gazzâlî usul hattının da aynı kanaatleri paylaşması, Şâfiî mezhebinde imamın görüşünün bütünüyle sürdürülmesini zorlaştırmıştır. Cüveynî ve onu takip edenler, İbn Süreyc ve Ebû İshak el-Mervezînnin fürû-i fıkıh alanındaki tespitlerini Bâkıllânî ve Basrînin argümanlarıyla birleştirerek Şâfiînnin teorisini terkettiler. Bu teoriyi kendileri açısından savunulamaz bir noktaya taşıyan mütekellimîn çizgisindeki usulcüler, Kur’an ile Sünnet'i hücciyet değeri bakımından özdeş hale getirirken, mezhebin diğer kanadını temsil eden usulcülerden Semânî Sünnet'i Kur'an'dan belli noktalarda ayrıştırmaya özen gösterdi. Semânî ve Şîrâzî bu konuda imamlarını bütünüyle yalnız bırakmak istemeseler de neticede çapraz neshin bir yönünde ondan ayrıldılar ve mezhepte Şâfiîyi bütünüyle takip eden kimse kalmadı.

Çapraz nesih konusunda imamlarının görüşünü paylaşmayan Şâfiî usulcülerinin yönelttikleri tenkitlerin ve hareket ettikleri noktaların Hanefî ve Mâlikî usulcüleri tarafından da paylaşılması, âdeta Şâfiî karşısında ortak bir cephenin oluşmasını sağladı. Meselenin nassa ziyadenin mahiyeti tartışması gibi bazı uzanımları hususunda farklı kanaatleri paylaşmalarına rağmen neshin mahiyeti, Hz. Peygamber'in beyan vazifesinin anlamı ve çerçevesi ve bu bağlamda Kur'an-Sünnet ilişkisine dair elde edilen uzlaşı, Şâfî̀nin kendi dönemindeki bazı çevrelere karşı taşıdığı hassasiyetlerin zamanla anlamını yitirdiğini ve usulcülerin bu noktada bir uzlaşı elde ettiklerini göstermektedir. Tikel nesih örnekleri üzerindeki tartışmalara usul eserlerinde devam edilse de Kur’an’ın sünneti neshi hemen bütün usulcüler tarafından benimsenmiş, sünnetin Kur'an’ neshi ise çoğunluğun savunmakta mahzur görmediği bir görüş haline gelmiştir.

\section{Bibliyografya}

Aktepe, İshak Emin, “İmam Şâfîi’nin Ehl-i Kelâm ve Mâlikîlere Karşı Hadis Savunusu”, Hadis Tetkikleri Dergisi, 6/1 (2008): 111-33.

Altay, Şeyma, "Mukâtil b. Süleyman Örneğinde Erken Dönem Nesih Algısı”, Usûl: İslam Araştırmaları, 23 (2015): 45-66.

Âmidî, Seyfeddin, el-İhkâm fî usûli’l-ahkâm, nşr. Abdürrezzâk Afîfî, I-IV, Beyrut - Dımaşk: el-Mektebü'l-İslamî, t.y.

Bâcî, İhkâmüll-fusûl fî ahkâmi'l-usûl, nşr. Abdülmecid Türkî, I-II, Beyrut: Dârü'l-garbi'lİslamî, 1407/1986. 
Beroje, Sahip, “İmam Şafiînnin Nesh Anlayışı ve İlk Şâfiî Usulcülerin Buna Yönelik Eleştirileri”, Dicle Üniversitesi İlahiyat Fakültesi Dergisi, 9/1 (2007): 53-82.

Birışık, Abdülhamit, “Nesih”, DİA, 2006, XXXII, 584-586.

Boynukalın, Ertuğrul, İbn Cerîr et-Taberî ve Fıkıh Düşüncesi, İstanbul: Ocak Yayıncılık, 2011.

Burton, John, The Sources of Islamic Law: Islamic Theories of Abrogation, Edinburgh: Edinburgh University, 1990.

Büveytî, Muhtasarüll-Büveytî, nşr. Ali Muhyiddin el-Karadâğ̂̀, Beyrut: Dârü’l-minhâc, $1436 / 2015$.

Cessâs, el-Fusûl fill-usûl, nşr. Uceyl Câsim en-Neşemî, I-IV, Küveyt: Vizâretü’l-evkāf ve'şşuûni'l-İslamiyye, 1405/1985.

Cüveynî, İmâmü'l-Haremeyn, el-Burhân fî usûli'l-fikh, I-II, Beyrut: Dârü'l-kütübi'lilmiyye, 1418/1997.

Cüveynî, İmâmü'l-Haremeyn, et-Telhîs fî usûli'l-fikh, nşr. Abdullah Cevlem en-Nîbâlî Şübbeyr Ahmed el-Ömerî, I-III, Beyrut: Dârü'l-beşâiri'l-İslamiyye, 1417/1996.

Ebû Hanîfe, el-Âlim ve’l-müteallim, İmam-ı Azam’nn Beş Eseri içinde, trc. Mustafa Öz, İstanbul: Marmara Üniversitesi İlâhiyat Fakültesi Vakfı (İFAV), 1992.

Ebû Ubeyd, Kāsım b. Sellâm, en-Nâsih ve'l-mensûh fi'l-Kurâni'l-azîz, nşr. Muhammed b. Sâlih el-Müdeyfir, Riyad: Mektebetürr-Rüşd, 1418/1997.

Ebül-Hüseyin el-Basrî, el-Mu'temed, nşr. Halîl el-Meys, I-II, Beyrut: Dârü'l-kütübỉlilmiyye, 1403/1983.

Erdem, Erol, Şâfiî Usûlcülerin İmam Şâfî̀nin Usûlünü Temsil Sorunu: Beyan, Âmm-Hâss, Nesh, Haber-i Vahid (doktora tezi, 2008), Selçuk Üniversitesi Sosyal Bilimler Enstitüsü.

Eşaraî, Ebü’l-Hasan, Makālâtü̉l-İslâmiyyîn, nşr. M. Muhyiddin Abdülhamîd, I-II, Beyrut: el-Mektebetü'l-asriyye, 1426/1995.

Fahreddin er-Râzî, el-Mahsûl, nşr. Tâhâ Câbir el-Alvânî, I-VI, Beyrut: Müessesetü’r-risâle, $1418 / 1997$.

Gazzâlî, el-Menhûl, nşr. M. Hasan Heyto, Dımaşk: Dârü’l-fikr, 1400/1980.

Gazzâlî, el-Müstasfâ min ilmi'l-usûl, I-II, Beyrut: Dâru ihyâi't-türâsi'l-Arabî, 1324.

Gürkan, Menderes, "İmam Şafiî Öncesi Nesih Kavramı ve Şafiînnin Deliller Arası Nesih Anlayışı”, Uluslararası İmam Şafiìi Sempozyumu, ed. Mehmet Bilen, İstanbul: Kent Işıkları, 2012, s. 836-56.

İbn Fûrek, Mücerredü makālâtişs-Şeyh Ebi'l-Hasan el-Eşararî, nşr. D. Gimaret, Beyrut: Dârü’lMeşrik, 1987.

İbn Huzeyme, Sahîhu İbn Huzeyme, nşr. M. Mustafa el-A‘zamî, I-IV, Beyrut: el-Mektebü’lİslamî, 1975.

İbn Kesîr, Ebü’l-Fidâ, Tefsîrüll-Kur'âni’l-azîm, nşr. M. İbrâhim el-Bennâ v.dğr., I-VIII, İstanbul: Kahraman Yayınları, 1984.

İltaş, Davut, Klasik Nesih Teorisi ve Çağdaş Tefsirciler, Ankara: Ankara Okulu Yayınları, 2016.

İsnevî, Nihâyetü’s-sûl şerhu Minhâcil-vüsûl, Beyrut: Dârül-kütübi'l-ilmiyye, 1420/1999. 
Karâfî, Şehâbeddin, Şerhu Tenkìhi'l-fusûl, Beyrut: Dârü'l-fikr, 1424/2004.

Koca, Ferhat, İslâm Hukuk Metodolojisinde Tahsis, İstanbul: İSAM Yayınları, 1996.

Lowry, Joseph E., Early Islamic Legal Theory: The Risāla of Muhammad b. Idrīs al-Shāfi ì, Leiden: Brill, 2007.

Mâverdî, el-Hâvi'l-kebîr fî fikhi mezhebill-İmâm eş-Şâfî̀, nşr. Ali Muhammed Muavvaz Âdil Ahmed Abdülmevcûd, I-XVIII, Beyrut: Dârüll-kütübi'l-ilmiyye, 1414/1994.

Mekkî, Muvaffak b. Ahmed, Menâkıbü Ebî Hanîfe, Beyrut: Dârü'l-kitâbi'l-Arabî, 1401/1981.

Melchert, Christopher, "IX. [III.] Yüzyıl Boyunca Nesih: Şafiî, Ebû Ubeyd, Muhâsibî ve İbn Kuteybe", trc. Nail Okuyucu, Marmara Üniversitesi İlâhiyat Fakültesi Dergisi, 40 (2011): 201-22.

Mervezî, Muhammed b. Nasr, es-Sünne, nşr. Ebû Usâme Selîm b. Îyd el-Hilâlî, Küveyt: Müessesetü Gırâs li’n-neşr ve’t-tevzî̀, 1426/2005.

Müslim b. Haccâc, Sahîhu Müslim, I-III, İstanbul: Çağrı Yayınları, 1413/1992.

Nehhâs, en-Nâsih ve’l-mensûh, nşr. Muhammed Abdüsselâm Muhammed, Küveyt: Mektebetü'l-felâh, 1408/1988.

Okuyucu, Nail, Şâfiî Mezhebinin Teşekkül Süreci, İstanbul: İFAV Yayınları, 2015.

Okuyucu, Nail, "Shâfi'î Usûl Thought in Late Third-Century Ah: Edition, Translation, and Interpretation of Chapters on Usûl al-Fiqh in al-Wadầ' by Ibn Surayj (d. 306/918)", Ilahiyat Studies: A Journal on Islamic and Religious Studies, 7/1 (2016): 87-133.

Sem ‘ânî, Ebü’l-Muzaffer, Kavâtıu’l-edille fil-usûl, nşr. M. Hasan İsmâil eş-Şâfiî, I-II, Beyrut: Dârü'l-kütübi'l-ilmiyye, 1418/1999.

Sübkî, Takıyyüddin - Tâceddin es-Sübkî, el-İbhâc fî şerhi'l-Minhâc, I-III, Beyrut: Dârü’lkütübi'l-ilmiyye, 1416/1995.

Şâfiî, er-Risâle, nşr. Ahmed M. Şâkir, Kahire: Mektebetü'l-Halebî, 1358/1940.

Şâfiî, The Epistle on Legal Theory, çev. Joseph E. Lowry, New York: New York University Press, 2013.

Şah Veliyyullah, el-Fevzü̉l-kebîr fî usûlit-tefsîr, çev. Selmân el-Hüseynî en-Nedvî, Kahire: Dârü's-sahve, 1407/1986.

Şâtıbî, İbrâhim b. Mûsâ, el-Muvâfakāt fî usûliłş-şerîa, nşr. Ebû Ubeyde Meşhûr b. Hasan Âlü Selmân, I-VII, Huber: Dâru İbn Affân, 1417/1997.

Şîrâzî, Ebû İshak, et-Tebsıra fî usûli’l-fikh, nşr. M. Hasan Heyto, Dımaşk: Dârü'l-fikr, $1403 / 1983$.

Şîrâzî, Ebû İshak, Şerhu'l-Lüma', nşr. Abdülmecîd Türkî, I-II, Beyrut: Dârü’l-garbi'l-İslamî, $1408 / 1988$.

Tok, Fatih, “Ebû Hanîfe’nin Nesih Anlayışı”, Usûl: İslam Araştırmaları, 24 (2015): 7-32.

Tûfî, Şerhu Muhtasarir-Ravza, nşr. Abdullah b. Abdülmuhsin et-Türkî I-III, Beyrut: Müessesetü'r-risâle, 1407/1987.

Zerkeşî, Bedreddin, el-Bahrü'l-muhît fî usûli’-fikh, I-VI, Abdülkādir Abdullah el-Ânî v.dğr., Küveyt 1413/1992.

Zeyd, Mustafa, en-Nesh fi'l-Kurâni'l-Kerîm: Dirâse teşrîiyye târîhiyye nakdiyye, I-II, Mansûre: Dârü'l-vefâ, 1408/1987. 


\section{Al-Shāfi'īs Theory of Intra-source Abrogation and its Interpretations in Shāfi'ī School of Thought}

Personal schools of legal thought began to form towards the end of first Islamic century and varied in respect to the circle, teacher, and methodology. The transformation of these personal schools into doctrinal schools by the middle of the second century was an important turning point in Islamic legal history. The studies of Mālik (d. 179/795) and his followers as the dominant jurisprudential thought in the Hijaz and the studies of Abū Haniffa (d. 150/767) and his followers as the dominant jurisprudential thought in Iraq turned into the Mālikī and Hanafí schools of thought. Testifying personally to this process, al-Shāfíi (d. 204/820) developed a particular approach to sources distinct from the two prevalent schools of Malikism and Hanafism. This approach raised the authority of oral reports, transmitting both the Prophet's tradition and the earliest Islamic experience, and intended to define jurisprudential reasoning (ijtihād). Al-Shāfi'i explained these two points in his famous work, al-Risäla, by identifying hadith with sunna and identifying ijtihād with qiyās (analogy). Therefore, in parallel to concentrating on studies of transmission, he both tried to assign a theoretical component to the approach of the people of the tradition (ahl al-hadith) by raising the legal value of individual transmissions and also stood against the legal background of other opponent circles. Ancient schools defended their ideas in the context of general legal principles as well as by accepting certain important assumptions. Al-Shāfi'i especially struggled against the Māliki approach of excluding many reports by relying on the Medina experience; and he challenged the Hanafĩ school by focusing on its regional legal background as well as its general legal theory of analogy and juristic preference (istiḥsān). Al-Shāfíîs treatment of abrogation and particularly his approach to cross-source abrogation constituted a significant part of his endeavor to raise the legal value of hadith.

The question of abrogation that had been debated for the first two centuries of Islamic history took on a new dimension due to al-Shāfiî̀s aforementioned theory of source. The most salient aspect of his idea of abrogation was his opposition to cross-source abrogation between the Quran and sunna. In accordance with his theory of source and interpretation that he developed through the concept of statement (bayān), Al-Shāfi'ì sought to assign a space to abrogation that would not belie the principles of this theory and devised the changes as examples of abrogation as an intra-source process. Finding cross-source abrogations unacceptable for his theory, al-Shāfi'i considered the abrogation of prophetic traditions by the Quran as a great threat to the reliability of hadiths and viewed the abrogation of Quran by prophetic traditions as an inverted process of statements. Al-Shāfíi who tried to apply this theory to the most widely known issues, had difficulty in explaining certain points despite his great effort and seemed to include prophetic traditions to an abrogation by Quran.

Although al-Shāfi'îs's theory of intra-source abrogation was adopted by his first students and jurists known as "People of Egypt," such as al-Buwayțī (d. 231/846) and al-Muzanī (d. 264/878), it was challenged by certain scholars among the 
second generation Shāfi îs. Some scholars from this generation-whose affiliation to Shāfíism was dubious and who deserve to be called among the people of tradition, such as Muhammad b. Nașr al-Marwazī (d. 294/906) and Ibn Khuzayma (d. 311/924), as well as al-Ṭabarī (d. 310/923), who turned into an independent jurist-adopted cross-source abrogation. Ibn Surayj (d. 306/918), who was a central figure in the formative period of the school due to his jurisprudential efforts, students, and works, seemed to adopt al-Shäfi î̀s theory of intra-source abrogation but added a new dimension to the debate by differentiating rational possibility, religious possibility, and actual occurrence, thereby paving the way for new interpretations within the school. Ibn Surayj's students sought possibilities of transforming the theory of abrogation without contradicting al-Shāfi îs theory of statement; after a certain date, their followers found an appropriate venue for abandoning the theory by ascribing multiple views to al-Shäfi'i. Some Shäfi'i scholars in the fourth/tenth century confessed to the difficulty of defending al-Shāfi'i on this point and openly expressed the necessity of abrogation of the prophetic tradition by the Quran by disregarding far-fetched interpretations.

Al-Juwaynī (d. 478/1085) and al-Ghazzālī (d. 505/1111), as scholars of theological theory, abandoned al-Shāfi îs theory of intra-source abrogation, especially by relying on al-Bāqillānī (d. 403/1013). These theologians-who developed a new approach to statement as the main concept for the approach to sources and interpretations and showed that cross-source abrogation did not belie the concept of statement-used al-Shāfi î̀s conclusions based on Quranic verses and turned these verses into evidence for the opposing views, redesigned the Quran-Sunna relations based on the holistic view of revelation, and sought to show that al-Shäfi'îs concern for the threat posed by cross-source abrogation for the prophetic tradition was unfounded. Al-Ghazzālī also adopts Al-Juwaynī’s challenges, which were partially based on al-Bāqillānīs views. As for Fakhr al-dīn al-Rāzī (d. $606 / 1210$ ), cross-source abrogation evolved into prevalent views among theologian Shāfi'ī theoreticians and commentators of al-Rāzìs works also adopted this position. Besides, Shirāzì (d. 476/1083) and Samānī (d. 489/1096), who had a distant position in respect to Asharī theology, could not abandon intra-source abrogation completely but continued defending their leaders in respect to abrogation of Quran by prophetic traditions.

This paper examines first al-Shāfi'îs's theory of intra-source abrogation in the legal context of the second/eighth century and investigates the background for his opposition to cross-source abrogation. It then traces how this theory of abrogation was received and treated, what kinds of challenges it faced, and how it was abandoned. To do so, it tries to identify the arguments of various scholars involved in this debate and highlight their novel contributions. Taking al-Shāfìi and Shafiism as example, the paper aims at demonstrating that the contextual meaning of a jurist's and a school's position and their approaches to some theoretical issues may change when the context differs. In addition, it tries to show that the jurisprudential affiliation may lose its importance in theoretical theological debates and theoretical disagreements may not align with school affiliations.

Keywords: Al-Shāfìīi, Qửān, Sunna, Islamic legal theory, mutakallimūn. 